University of California, Hastings College of the Law UC Hastings Scholarship Repository

Faculty Scholarship

$1-1-1995$

\title{
Private Voluntary Standard-Setting, the International Organization for Standardization, and International Environmental Lawmaking
}

Naomi Roht-Arriaza

UC Hastings College of the Law, rohtarri@uchastings.edu

Follow this and additional works at: https://repository.uchastings.edu/faculty_scholarship

\section{Recommended Citation}

Naomi Roht-Arriaza, Private Voluntary Standard-Setting, the International Organization for Standardization, and International Environmental Lawmaking, 6 Y.B. Int'l Envtl. L. 107 (1995).

Available at: https://repository.uchastings.edu/faculty_scholarship/1298

This Article is brought to you for free and open access by UC Hastings Scholarship Repository. It has been accepted for inclusion in Faculty Scholarship by an authorized administrator of UC Hastings Scholarship Repository. For more information, please contact wangangela@uchastings.edu. 


\title{
Private Voluntary Standard-Setting, the International Organization for Standardization, and International Environmental Lawmaking
}

\author{
Naomi Roht-Arriaza
}

\section{INTRODUCTION}

As the 21 st century approaches, environmental regulation around the world is slowly moving away from simple reliance on "command-and-control" rules toward approaches like taxes, tradeable permits, auditing and management schemes, and eco-labels. A salient feature of this shift is the increased use of self-regulatory, consumer-based, and voluntary mechanisms to allow enterprises to move "beyond compliance." Several underlying assumptions power the shift, including the exhaustion of the gains that can be realized through regulation alone, the realization that reducing pollution and waste can often save money and make companies more efficient, ${ }^{1}$ and the conviction that market forces can be harnessed effectively for environmental ends if the relevant actors have sufficient information. At the same time, industry has grown increasingly dissatisfied with government regulation, which is criticized as reducing competitiveness and costing jobs.

Although environmental mechanisms relying on market forces originated in national arenas, in an era of globalized business, their proliferation has led quickly to attempts to harmonize such mechanisms on a regional and international level. International environmental law is still clearly dominated by state-based treaty and "soft law," nonetheless, it increasingly intersects, and must take into account, privately generated and implemented rules. These rules include private standards, codes of conduct, and agreements on environmental measures to be carried out by specific enterprises, sectors, or firms. The genesis of these standards and rules is a complex mix of competitive pressures, a desire to avoid further national and international regulation and to roll back existing rules, a need to harmonize and

Some of the material in this article was published in 22 Ecology L.Q. 479 (1995). Many thanks to Professor Günther Handl for editing suggestions and to Jennifer Haworth for research assistance.

1 See e.g., Office of Technology Assessment, US Congress, OTA-ITE-317, Serious Reduction of Hazardous Waste: For Pollution Prevention and Industrial Efficiency 3-6 (1986). 


\section{IO8 YEARBOOK OF INTERNATIONAL ENVIRONMENTAL LAW}

standardize national rules across markets, and genuine attempts to "green industry." As these private sources of standards and rules begin to be implemented, they may well become increasingly less "voluntary," as pressure from consumers, suppliers, competitors, banks, insurance companies, and the like make them de facto mandatory in one or more major markets.

This article looks at the impact of international, private voluntary standards in the environmental arena, with its significant ramifications for public policy. It pays particular attention to the 14000 series standards now being developed by the International Organization for Standardization (ISO). It concludes that while market-enforced standards have a role to play in overall environmental-protection efforts, the ISO 14000 standards may add little and may, in several ways, set back efforts at corporate and industrial environmental responsibility. The biggest limitations to the standard are the lack of any substantive performance targets and of any requirement to make public information on environmental performance. Compared to public international lawmaking efforts, and even to other private codes of conduct, the results of the private process are much more limited.

Nonetheless, the process of elaborating the standards raises interesting questions for international environmental lawyers. In an age when the public resources available for both standard-setting and, especially, implementation and enforcement of public international agreements are woefully inadequate, a system in which market forces and private capital are enlisted to pull toward compliance with norms of environmental protection would have distinct advantages. Moreover, a system of private, voluntary standards might allow for direct focus on the sources of environmental problems, especially industrial activity. Rather than rely on states to transfer the international rules and standards into national law and regulation and then apply these to regulated entities, a private, voluntary system would focus directly on the regulated entities themselves. Such a system could harness the global market to reward environmentally preferable behavior and discourage that which is environmentally predatory. Finally, the process of creating private, voluntary standards raises questions about the effect of diversifying the direct actors in global rulemaking to include more than states, and about the impact of private standards on the current debates about trade and the environment.

The regulatory paradigm of the $1970 \mathrm{~s}$, based on emissions limits that industry had to meet by installing scrubbers, filters, and other "end-of-thepipe" devices, is now widely recognized as inadequate. ${ }^{2}$ In its place, regula-

2 See generally Bruce Ackerman \& Richard Stewart, Reforming Environmental Law, 37 Stan. L.R. 1333 (1985); Barry Commoner, Making Peace with the Planet (1992); Stuart L. Deutsch, Setting Priorities: Principles to Improve Environmental Policy, 68 ChI.-Kent L. Rev. 43 (1992). While some commentators argue that "command and control" must remain as a base for other approaches, most agree that further improvements will require additional 
tory agencies in many developed countries are moving slowly and tentatively toward a "pollution prevention" paradigm. Its purpose is to reduce pollution at the source before it is created by changing inputs into production and distribution processes. For example, the US Environmental Protection Agency (EPA) has urged industry participation in voluntary toxics reduction (33/50 program) and energy efficiency (green lights program), has begun integrating source reduction into agency regulations, works with specific industry sectors to minimize pollution through its "design for the environment" program, and provides grants for states for innovation in pollution prevention. ${ }^{3}$ It has also begun awarding the equivalent of eco-labels to "energy star" computers that use energy efficiently. ${ }^{4}$ The Common Sense, Environmental Leadership, and Project XL initiatives also fall to a greater or lesser degree under this rubric. ${ }^{5}$ Moreover, the United States has recently started using procurement to create a market in environmentally preferable goods; Executive Order $12873^{6}$ requires government agencies to use recycled paper, tires, and other such "environmentally preferable" goods wherever possible. ${ }^{7}$ Japan, too, is making greater use of such "pollution prevention" activity. ${ }^{8}$

tools. See, e.g., Howard Latin, Ideal Versus Real Regulatory Efficiency: Implementation of Uniform Standards and "Fine Tuning" Regulatory Reforms, 37 Stan. L. Rev. 1267, 1267-73 (1985).

3 US Environmental Protection Agency Office of Pollution Prevention and Toxics, E.P.A. Pollution Prevention Accomplishments: 1993 (1994). The 1990 Pollution Prevention Act required EPA to set up an Office of Pollution Prevention and to work with states to develop innovative approaches to prevention. Pollution Prevention Act, 42 U.S.C. $\$ \$ 13101-13109$. For discussion of several promising approaches, see RETHINKING THE Materials We Use: A New Focus for Pollution Policy (Ken Geiser \& Frances H. Irwin eds., 1993). See generally Robert F. Blomquist, Government's Role Regarding Industrial Pollution Prevention in the United States, 29 GA. L. REv. 349 (1995), especially the list of sources on pollution prevention at note 231; Ken Geiser, The Unfinished Business of Pollution Prevention, 29 GA. L. Rev. 473 (1995).

4 US Environmental Protection Agency Office of Pollution Prevention and Toxics, supra note 3

${ }^{5}$ The Common Sense Initiative involves developing a holistic approach to permitting based on industry sectors rather than pollutant or media. CSI, Leadership Programs at EPA May Use ISO 14000 Management Standards, Official Says 26 Env't REP. (BNA) 257 (1995). The Environmental Leadership Program entails a promise from EPA not to perform routine enforcement inspections in exchange for the participating plants using audits and otherwise taking steps to ensure that they are complying with applicable environmental standards. Project XL goes further, with EPA offering to release businesses from some regulatory requirements if they exceed current environmental standards. Inspections at Plants to be Suspended in Environmental Leadership Pilot Program, 25 Env'T ReP. (BNA) 2448 (1995).

6 Executive Order 12873, 3 C.F.R. 659 (1993 Comp.).

7 "Environmentally preferable" means "products or services that have a lesser or reduced effect on human health and the environment when compared with competing products or services that serve the same purpose." Id. \$201. The Executive Order creates a Federal Environmental Executive within EPA to oversee federal agency compliance with the order, to develop criteria for preferable products, and to disseminate information on waste prevention and reduction and market sources of recycled or environmentally preferable goods. Id. $\$ 301$.

${ }^{8}$ Japan in 1993 promulgated a new Fundamental Act for Environment stressing prevention of environmental pollution and energy conservation. Pollution prevention agreements between 
The European Community (EC) is moving toward similar market- and information-driven environmental incentive programs. The EC's Fifth Environmental Action Programme combines a multi-media, sectoral approach with a commitment to broadening the range of policy instruments and to increased use of non-regulatory mechanisms. ${ }^{9}$ The proposed Integrated Pollution Control Directive and the eco-labelling and eco-audit schemes throughout the European Union (EU) are also part of this shift. In several European countries, governments have entered into voluntary agreements with one or more industrial sectors to reduce or eliminate certain harmful substances or practices. ${ }^{10}$ These agreements act like private contracts, enforceable under civil law, and contain elements of industry self regulation and self monitoring subject to outside verification. Such sector-wide voluntary agreements are now being discussed on an EU-wide level, and there may shortly be pan-European voluntary agreements between the European Commission and certain industrial sectors. ${ }^{11}$

This article, while focusing on the ISO 14000 series standards, discusses two kinds of private, voluntary standards. The most developed and prevalent are process-focused environmental management and auditing standards. These are generally applicable to any kind of industry and focus on setting up and monitoring appropriate systems; no specific substantive limits or prohibitions are involved. Environmental improvement is assumed to result from increased internal knowledge and a general commitment to continual improvement. In some cases, internal knowledge is combined with requirements for public disclosure of impacts, on the theory that disclosure

industry and local government have been in place for a number of years. Shiro Kawashima, $A$ Survey of Environmental Law and Policy in Japan, 20 N.C.J. INT'L L. \& Com. Reg. 231, 248, 261 (1995). Amendments to Japan's Waste Disposal Law stress source reduction, while the Law for Promoting the Utilization of Recycled Resources designates certain industries, products, and by-products for recycling and provides incentive schemes for companies and individuals to recycle. Misutsune Yamaguchi, Japanese Companies and the Environment, $24 \mathrm{~L}$. JAPAN 62, 75-76 (1991).

9 See, e.g., the emphasis in the Fifth Environmental Action Programme on market incentives, on actions targeted at industry, and on broadening the range of instruments. Commission of the European Communities, 1993 OJ C 138, Towards Sustainability: European Community Programme of Policy and Action in Relation to the Environment and Sustainable Development (Fifth Environmental Action Programme) (May 17, 1993); see also the proposed Integrated Pollution Prevention and Control directive, which would establish a multi-media, pollution-prevention based approach to industrial pollution problems. Commission of the European Communities, 1995 OJ C 165, Amended Proposal for a Council Directive concerning Integrated Pollution Prevention and Control (May 15, 1995 , COM/95/88 final, published July 1 , 1995). The use of voluntary measures in the latest proposal for a carbon tax might be another example.

${ }_{10}$ See discussion infra note 217 and accompanying text.

11 Jesper Jorgensen, European Commission, DG XI, Foreseen Future Initiative from the European Commission Concerning the Use of Negotiated Agreements in the Field of Environmental Policy, speech given at Conference on Voluntary Approaches for Mitigating Energy-Related $\mathrm{CO}_{2}$ Emissions, (Oct. 30-31, 1995) (transcript on file with author). 
will lead to additional pressure for improvement. The article first briefly considers under this heading corporate codes of conduct. It then turns to the European Management and Auditing System (EMAS) regulation. Finally, this section analyzes the emerging environmental management standards of the ISO 14000 series.

A second group of voluntary standards focuses on products and the processes associated with their production, use, and disposal. These standards attempt to reward goods exhibiting environmentally preferable traits in their production, distribution, use, and disposal with an eco-label that will induce consumers to buy the environmentally superior product. The dominant form of eco-labelling does not, by definition, extend to all products, but rather aims at the top 10-20\%, hoping to use consumer preference to raise standards for the entire product line. Again, eco-labelling programs originated within a number of different states, but harmonization efforts are currently underway in the ISO and among the labelling programs themselves.

The process by which both these types of global standards are being crafted and debated raises a number of interesting issues about their relationship to public international law. The article focuses on the innovative features of standard-setting within the ISO and places them within a larger context that includes opening up rulemaking processes once reserved exclusively to states to multiple interests. It then looks at the limitations of the process used to draft the ISO 14000 standards, and compares the standards to publicly generated rules on related topics.

A final section considers the possibilities for effectiveness of private, voluntary standards. It first looks at how the standards may be used, and especially at how they intersect with existing international trade regimes. It concludes that process-focused management standards will be insufficient and that substantive standards will eventually prove necessary. The article looks to the existing precedents in the area of company- or plant-based standards that focus on substantive changes and limits on processes, materials, and emissions. These standards are generally sectorally based and have affected mostly industry groups characterized by a small number of large companies, a highly polluting process, and high public visibility. Finally, the article discusses the potential advantages of producer- or product-based standards and explores the necessary preconditions for such standards to evoke compliance.

\section{PROCESS-FOCUSED MANAGEMENT AND AUDIT PROGRAMS}

\section{A. Business Codes of Conduct}

Several business groups have supported international standards for environmental performance. In 1991, the Business Council for Sustainable 
Development $(\mathrm{BCSD})^{12}$ suggested creating international standards that would allow businesses in various sectors to measure their environmental impacts according to comparable criteria. ${ }^{13}$ The BCSD's initiative dovetailed with various other efforts at corporate environmental responsibility. In 1989, a coalition of socially responsible investors in the United States published the "Valdez Principles," a set of voluntary commitments intended to be used by investors to favor environmentally responsible corporations. Corporations that signed on to the principles were supposed to: minimize pollutants, resource and energy use, and waste generation; inform consumers of the environmental impacts of their products and services; complete and make public an annual self-audit of environmental progress and work toward creating independent environmental audit procedures to be made available to the public; and establish management and Board structures to oversee environmental performance. ${ }^{14}$

Two years later, the International Chamber of Commerce created the Business Charter for Sustainable Development in response to recommendations in the 1987 Bruntland Commission Report. ${ }^{15}$ The Charter's principles include: commitment to a process of environmental assessment and improvement of policies, programmes, and performance, including applying the same environmental criteria internationally; design and operation of facilities and activities to use energy and materials efficiently and sustainably, minimize adverse environmental impact and waste generation, and dispose of residual wastes safely; application of the precautionary principle; and a promise to pressure suppliers to comply with similar principles. Charter companies must also measure environmental performance, conduct regular audits, and "provide appropriate information" to the public. To join, companies simply sign up; public pressure is the only means of monitoring compliance with the commitment. The Global Environmental

\footnotetext{
12 In 1994, the BCSD merged with the World Industrial Council for the Environment to form the World Business Council for Sustainable Development. New Organization Formed From Merging of Business Groups Focused on Environment, 17 INT'L ENVTL. ReP. (BNA) 1011 (1994).

${ }^{13}$ Stephan Schmidheiny \& Business Council for Sustainable Development, Changing Course: A Global Business Perspective on Development and the Environment (1992); Stephan Schmidheiny, The Business Logic of Sustainable Development, 27 Colum. J. World Bus. 18 (1992).

${ }^{14}$ The Valdez Principles were eventually renamed the CERES Principles. 1990 CERES Guide to the Valdez Principles, in John R. Salter, Corporate Environmental Responsibility: Law and Practice 257, App. 10 (1992).

${ }_{15}$ The Charter was one of several projects by European and North American business leaders at the May 1990 Bergen Conference "Action for a Common Future," which was itself a follow-up to the Report of the World Commission on Environment and Development (Bruntland Commission), OUR COMmON Future, which established the concept of "sustainable development" as a goal. SALTER, supra note 14, at 262, App. 11. Almost 500 companies worldwide have now signed onto the Charter.
} 
Management Initiative (GEMI) established similar principles of "sustainable development." 16

Sectoral codes of conduct also appeared. The best-known is the Chemical Manufacturers Association (CMA) "Responsible Care" program, which binds all CMA members. ${ }^{17}$ The Responsible Care movement began in the 1980s in Canada, as a chemical industry response to negative public perceptions regarding the chemical industry's seeming indifference to environmental issues, especially after the Bhopal disaster. ${ }^{18}$ Companies must sign on to 10 guiding principles and six codes of management practices, which set performance objectives in the areas of emergency response, pollution prevention, process safety, distribution of chemicals, employee health and safety, and product stewardship. ${ }^{19}$ These must be implemented by all CMA members by 1999. A 15-member public advisory panel counsels the CMA, and member companies gauge their progress through yearly self evaluations. ${ }^{20}$

Adherence to the principles and codes is theoretically assured because noncompliance may lead to expulsion from the industry trade association, with the associated public-relations problems. Critics argue, however, that the codes are written so broadly that almost anything can fit into them, that only three of the six codes have performance indicators and that even those merely reflect existing domestic legal obligations. Further, critics have pointed out the insufficiency of self evaluation for monitoring progress. To meet that criticism, the CMA in June 1994 approved the use of an experimental third-party verification system, but to evaluate only the management and assessment systems themselves, rather than the actual results of implementation. ${ }^{21}$ Finally, those critical of the CMA approach questioned the lack of any requirement to disclose the results of evaluations, and the nonsite-specific nature of the data released by the industry to show improvement. 22

16 As of December 1995, 26 multinational firms in the United States had signed GEMI. GEMI Companies Honored at Environmental Champions Award Ceremony, PR Newswire, Dec. 4, 1995 available in LEXIS, World Library, CURNWS file. See also Anthony D. Cortese, Environmental Laws Under the Nation States, in TransNational ENVIRONMENTAL LAW AND ITs IMPACT ON CORPORATE BEHAVIOR 44 (Eric J. Urbani et al. eds., 1994).

17 The CMA issued the Responsible Care Program in 1991 as a way to assuage public concerns about chemicals and the industry. In addition to rather general principles regarding safe chemical development, production, transportation, use, and the reporting of chemical-related hazards, the Program includes a public advisory panel and a code of management practices with specific management objectives. See Salter, supra note 14, at 268, App. 12. European producers adhere to a similar set of principles.

${ }_{18}$ The Responsible Care Movement, EuR. Envtl. L. Rev., July 1993, at 189.

19 Lois R. Ember, Responsible Care: Chemical Makers Still Counting on it to Improve Image, Chemical \& Engineering News, May 29, 1995, at 10, 12.

$20 I d$. at 11 . At times, CMA calls in third-party evaluators to validate the self evaluations.

${ }^{21}$ CMA Gives Green Light to Third-Party Audits, Chemical Week, July 6-13, 1994, at 38 Compare to the similar requirements and limitations in the ISO standard, discussed below.

22 Ember, supra note 19, at 16. 


\section{II4 YEARBOOK OF INTERNATIONAL ENVIRONMENTAL LAW}

These industry-based initiatives were soon followed by more specific proposals in the areas of environmental management and auditing systems. The EC took the lead in trying to replace the various private schemes with a single set of criteria and requirements that would allow industries with operations in more than one country to avoid duplicating efforts and costs. The result was the Eco-Management and Audit Scheme. Although EMAS was established through government regulation, it is voluntary and relies wholly on market mechanisms for effectiveness. ${ }^{23}$ The existence of EMAS, in turn, provided part of the impetus for a more encompassing effort at creating an international environmental management standard. That effort has been housed in the ISO. ${ }^{24}$

\section{B. The Eco-Management and Audit Scheme of the European Union}

As part of the Fifth Environmental Programme's effort to encourage industry to play a pro-active, cooperative role in environmental protection, EU Council Regulation 1836/93 establishes a voluntary system for using internal management and auditing systems to achieve continuous improvement in environmental performance. While the regulation dates from 1993, it only became effective as of April 1995. ${ }^{25}$ It is to be revisited and possibly revised in five years; at that time the EU will decide whether to make it compulsory.

Companies may register industrial sites participating in the program and publicize the fact of registration. According to EMAS' backers, participation in the program will benefit a company through improved public image, better relationships with employees, planners, regulators, and the local community, and through the possibility of increased market share, cost avoidance (for accidents, insurance premiums, fines, and the like) and cost reduction. ${ }^{26}$

EMAS registration is granted on a site-specific basis. While companies may be headquartered anywhere in the world, only those sites physically located in an EU member state may be registered. The regulation requires a company seeking registration for one or more industrial sites to carry out an environmental review; to elaborate and implement an environmental policy, environmental objectives, and programs; to carry out an environmental audit; to publish a statement of findings; and to submit to outside verification. The initial environmental review must consider 11 parameters

${ }^{23}$ Council Regulation 1836/93, Establishing a European Eco-Management and Audit Scheme, 1993 O.J.(L 168) 1 [hereinafter EMAS].

${ }^{24}$ The ISO 14000 series specification and guidance standards are, as of this writing, in draft form only; the first standard is expected to be approved by mid-1996.

${ }^{25}$ Peter Wilson, The Community Eco-Management and Audit Scheme: An Overview, Progress to Date and Current Issues, EC Commission, DG XI.E.I, Oct. 18, 1995, at 4 (on file with author). Implementation to date of EMAS is discussed following note 31.

26 KPMG Environmental Advisors, EMAS, An Introductory Guide 4-7 (1995). 
set out in an Annex to the regulation, including actual and potential environmental impacts to air, water, land, and natural resources; energy use; materials and goods used; waste disposal; accidents; and the potential effects of new products and new or changed production processes. The environmental performance of contractors, sub-contractors, and suppliers and the need to influence and control their activities must also be addressed. Based on this review, each site is to have a register of significant environmental effects.

Based on the results of the review, an environmental policy, objectives, and programmes must be developed and implemented. The policy must commit to a series of good management practices, including preventing and eliminating pollution where feasible, assessment and monitoring, and providing information and advice to the public and customers. The objectives are to be quantifiable (where practicable), time-limited, and periodically reviewed. All legislative, regulatory, and policy requirements are to be recorded; performance is to be monitored and documented; and procedures must be in place for correcting non-performance.

Three mechanisms ensure the integrity of the EMAS process. First, registration of each site is conditioned on periodic auditing to ensure compliance with company policy, objectives, and programmes as well as with relevant regulatory requirements. Second, a public environmental statement must be prepared. The statement must include a summary of figures on pollutant emissions, waste generation, use of raw materials, energy and water, noise, and other significant effects, an assessment of significant issues, a description of company environmental policy and of the program and management systems at the particular site, and the name of the accredited environmental verifier. Thus, local community and environmental pressure groups will have enough information to monitor a site's current situation and evaluate improvements. Third, to obtain registration, each site must be checked by an external "verifier" independent of the auditor. The verifier must assure that all reviews, audits, and other elements of the scheme have been properly carried out, that the data provided in the environmental statement is reliable and complete, and that the site meets all EMAS requirements.

Member states participate in EMAS through the designation of the competent body to process applications for registration, and through an accreditation body that sets the standards and grants accreditation to professional verifiers. Once the validated environmental statement is produced, it is up to a competent body designated by each member state to grant the site registration. The designation of a competent body has occasionally proven controversial; in Italy, for example, there was some debate as to whether it should be housed within the Environment or Industry ministries. ${ }^{27}$ Once a

27 Interview with Manfredi Bellati, DG XI (Directorate-General on Environment, Nuclear Safety, and Civil Protection) of the EC Commission, in Brussels, Belgium (Nov. 10, 1995). 
site has been registered, it maintains the registration through simplified annual statements combined with a three-year audit cycle. If the registration authority decides a site no longer complies, or if domestic enforcement authorities inform the designated competent body that the site is not in compliance with relevant environmental legislation, it may be de-registered. The accreditation body is to identify the requirements for individuals and/or companies and approve those that can act as verifiers. As of October 1995, EMAS accredited verifiers had been approved in only the United Kingdom, Denmark, and Germany, although some 200 applications for accreditation had been received. ${ }^{28}$ Verifiers can operate in any member state, but must be subject to supervision by the member state system in which they perform verification activities. After some initial confusion regarding the precise role of verifiers, the European Commission is preparing guidance documents on criteria for accrediting verifiers and on their activities.

The designation of both competent bodies and accreditation bodies has been slower than expected. By late 1995, three states had still not designated the appropriate national authorities, although all were expected to do so by early 1996. ${ }^{29}$ Moreover, companies with Europe-wide operations complained that some of the advantages of a region-wide scheme were undermined by potential inconsistencies caused by leaving criteria for verifiers up to each state, or even to sub-national entities. ${ }^{30}$ The Commission has an agreement with the European Organization for Testing and Certification to iron out the differences, but harmonized criteria are still some way off. ${ }^{31}$

By October 1995, five UK sites, two Danish sites, and six German sites had registered under EMAS. Chemical companies, already familiar with auditing and management schemes from industry-wide codes, are particularly well represented. To date, all registrations have been of large and medium-size companies. The cost and complexity of registration is one potential limit to the scheme, which may end up favoring large over small businesses. The Commission, well aware of this criticism, has prioritized outreach to small business, funding 32 pilot projects with some 400 businesses for training, informing, and incorporating eco-management principles into the operations of small and medium-sized enterprises.

While Commission officials are optimistic that registrations will pick up as the scheme becomes better known, some companies seem to be delaying

\footnotetext{
28 Commission of the European Community, List of EMAS ACCREdited Verifiers (updated to Oct. 25, 1995); WiLson, supra note 24, at 14.

29 Officials Say Greece, Spain, Portugal Still Lack Administrative Base for EMAS, 18 INT'L ENVTL. REP. (BNA) 862 (1995).

30 According to Spanish law, for example, each of 17 autonomous communities has the right to designate its own bodies for accreditation of verifiers, although in practice almost all will probably rely on a national agency.

31 Only Half of EU Member States Prepared for Participation in Eco-Management and Audit Scheme, 18 InT'L ENV'T DAILy (BNA), Apr. 24, 1995, at 310.
} 
until the relationship between EMAS and other national and international eco-management standards has been clarified. If one set of procedures and verifications can serve several registration schemes, the costs involved will decrease. The relationship between EMAS and other standards has been the most contentious issue in implementing the standard. In addition, the desire to meet the requirements of EMAS has been a driving force in the development and scope of international standards.

Article 12 of EU Council Regulation 1836/93 allows companies implementing and certified to national, European, or international standards to be deemed to meet all or part of the EMAS requirements under certain conditions. First, the European Commission must have recognized the standards through the body of member state officials set up under Article 19 of EMAS. Second, the standards must be certified by a body, like a national standards organization, recognized by the member state where the site is located. Recognition of several already-developed national standards on environmental management, for example the British BS7750, has been complicated by the unwillingness of some member states to allow national standards to play any role in EMAS. Thus, the Commission delayed recognizing existing British, Irish, and Spanish standards as satisfying the Article 12 criteria until February $1996 .{ }^{32}$ Eventually, the Commission hopes to publish equivalency guidelines highlighting areas of correspondence between different national standards and EMAS. Companies would then have to verify only those requirements of EMAS not already certified to the national standard.

The relationship between EMAS and the global environmental management standards being developed by the International Organization for Standardization is complex and still unresolved. The following section first discusses the development and content of the ISO 14000 standards, and then looks at that relationship.

\section{The ISO 14000 Series Standards}

The International Organization for Standardization was founded in 1946 to promote international standards to facilitate global trade. It is a federation of 100 national standards bodies, each of which is that body "most representative of standardization in its country". ${ }^{33}$ The member organizations provide most of the financing, staffing, and administrative and technical

32 Commission Recognizes National Standards under EMAS, European Commission Press Release IP/96/113, REUTER Eur. COMMUNITY REP., Feb. 9, 1996. Recognition of national standards took several years, and came only after an early Commission attempt to do so failed. Interview with Manfredi Bellati, supra note 27. According to another source, "Germany is opposed in principle to the idea of an optional route to EMAS registration, while the Austrians are said to be holding out for ISO 14000 to be adopted." ENDS REPORT 247, Aug. 1995, at 38 .

33 International Organization for Standardization, Memento 3 (1995). 
services for the committees. Each national committee determines its own composition; while some national committees are almost entirely composed of private interests, others have substantial government representation. The organization's complex structure is based on technical committees, which may, as needed, establish their subcommittees and working groups. Each national group delegates its own members and decides the positions they will take in the technical committees and subcommittees. The national groups may form technical advisory groups to develop unified national positions on proposed standards; these may, in turn, subdivide into subtechnical advisory groups. By the beginning of 1994, there were 182 technical committees, 630 subcommittees, 1,918 working groups and 24 ad hoc study groups. Each technical committee or subcommittee has a secretariat, while the less formal working groups have conveners. ${ }^{34}$ The ISO's headquarters in Geneva has a Central Secretariat that handles voting procedures, a General Assembly, a governing Council, and a Technical Board.

ISO's work products are known as International Standards. To date, there are 2,649 standards, mostly in the fields of mechanical engineering, basic chemicals, non-metallic materials, information processing, graphics, and photography. ${ }^{35}$ The process of creating a standard starts with the ISO Council's forming a technical committee. The members of the technical committee organize the work into its component parts, assigning tasks to subcommittees and working groups. Participants negotiate and discuss the drafts in the various subcommittees and working groups as well as in the national technical advisory groups. The various subcommittee and working group drafts are eventually integrated into a committee draft that must be approved by consensus. After the technical committee approves the draft, it becomes a "draft international standard," and is circulated to the entire ISO membership for a vote. A substantial majority must approve the standard for it to be published as an international standard.

ISO-approved documents may be either specification standards or guidance documents. Specification standards frame the standards' requirements and form the basis for third-party certification or verification. Guidance documents set out suggested methods and approaches for achieving the standard but do not themselves serve as the basis for certification. A given area may include a specification standard and a number of related guidance documents and aids to implementation.

\footnotetext{
34 While conveners oversee the actual draft standard writing at the working group level, the committees and subcommittees, headed by secretariats, are the bodies which promulgate the draft international standards which members vote on. See id. at 5. See also OfFICE OF Pollution Prevention and Toxics, US EPA, ISO 14000: International Environmental Management Standards 1 (1995).

35 International Organization for Standardization, ISO in Figures 3 (1994).
} 
(i) The Genesis of the ISO 14000 Series Standards

Several factors promoted ISO's involvement in environmental management standards. EMAS' approval led to complaints that global businesses were going to be subject to multiple, inconsistent sets of management and auditing standards, resulting in calls for a global standard to encompass and harmonize national and regional ones. The proliferation of private business codes of conduct led to similar calls for streamlining and harmonization. In addition, ISO affiliates were more willing to undertake the task because of the success of a related set of management standards, the ISO 9000 series quality control standards.

The ISO 9000 series quality control standards, published in 1987, contain guidelines for companies to use in implementing quality assurance systems ${ }^{36}$ and in specifying contract requirements for suppliers and subcontractors. ${ }^{37}$ The explicit goal was to harmonize quality assurance requirements to facilitate international trade. ${ }^{38}$ ISO 9000 represented a departure from conventional ISO work-products in two ways. First, ISO 9000 was the first international standard built more or less from scratch, rather than through harmonizing existing national standards. While both the United States and Europe had quality control standards of their own, there was no single "US" or "German" standard to bring to the table. ${ }^{39}$ Second, the standards were applicable to a wide range of industries and services, rather than a specific product, process, or plant.

The ISO 9000 series quickly became a de facto requirement for doing business in Europe and other parts of the world. Companies required proof

36 The ISO 9004 Quality Management Guidelines (9004, 9904-2, and 900-3) provide guidance for a firm wishing to use an ISO 9000 quality system for its inherent benefits, but not necessarily for certification. Perry L. Johnson, iso 9000: MeEting the New International STANDARDS 33 (1993).

37 ISO 9001, 9002, and 9003 apply to firms that seek ISO 9000 registration for legal or contractual purposes. Id. at 32-33.

38 Several provisions of ISO 9000 pointed the way toward more specific environmental management standards. ISO $9004 \$ 3.3$ declares that "in order to be successful, a company must offer products or services that ... comply with statutory (and other) requirements of society." These include "environmental considerations, health and safety factors, and conservation of energy and materials." Furthermore, the standard requires analysis of all phases in the life cycle of a product and processes, from initial identification of market needs to final satisfaction of requirements, including product design, production, packaging, storage, and disposal or recycling at the end of useful life. It provides for an internal audit of quality systems and periodic external evaluation. The standard requires that independent professional "registrars" evaluate a company's quality-control procedures and certify its compliance with the standard. Both the life-cycle assessment and internal/external audit approaches to quality have been incorporated into the ISO's current environmental standard setting. Thus, industry was already familiar with these concepts when it encountered them in an environmental context.

39 In the United States, early quality-control efforts were developed first by the Defense Department for military contractors, and by the "Big Three" automakers as proprietary systems for their suppliers. In Britain as well, quality control evolved from military specifications, but was promoted for the private sector by the British government. JoHNSON, supra note 36. 
through an independent, registered certifier that their suppliers and subcontractors complied with the standard ${ }^{40}$ ISO certification was required for certain regulated products covered by EC directives. ISO certification was also required in order to sell to government-controlled entities throughout Europe $^{41}$ In the United States, the National Aeronautics and Space Administration, the Food and Drug Administration, and the Defense Department began harmonizing their quality requirements to those of ISO $9000 .{ }^{42}$ The expanding use of the standard led US-based corporations to complain that certification was more expensive and difficult for them..$^{43}$ The difficulties arose in part because no accredited independent certifier was based in the United States, and in part because the EC would only accept its own certifiers. ${ }^{44}$ Some viewed the ISO standard, and especially the requirement for outside certification, as a non-tariff trade barrier designed to favor European industry. ${ }^{45}$ Others resented what they perceived as a European bias to the standard. These concerns, and a heightened awareness of the ISO standards' power to influence market behavior, have colored the process of designing the ISO 14000 series environmental standards.

A technical committee, TC 207, was officially launched in October 1992 with a mandate to develop standards in the areas of environmental management systems, environmental auditing, environmental performance evaluation, labelling, life-cycle analysis, and environmental aspects of product standards. Almost from the start, the environmental management system (EMS) standard has been the focus of much of the attention. In part this is because the EMS standard will be the certification standard, while those in

\footnotetext{
40 JoHnson, supra note 36 at $8-9$.

41 See Charles W. Thurston, Quality is a Global Affair: Worldwide Adoption of International Organization for Standardization Program, Quality '94, 246 CHEMICAL MARKeTING ReP. SR-10 (1994); Johnson, supra note 36, at 9; David Ong-Yeoh, Malaysia: Play by EU Rules to Enter its Mart, Investors Told, Bus. Times (Malaysia), Dec. 7, 1994, at 2 (companies must seek ISO 9000 certification to meet certain aspects of the essential requirements on imports into Europe).

42 See Thurston, supra note 41.

43 US-based corporations, according to a 1993 survey by Mobil Oil, accounted for only $4.7 \%$ of all certifications to the standard. British companies accounted for $62.5 \%$, other European companies for another $21.5 \%$, and those from Australia and New Zealand represented $7.1 \%$ of all certifications. Id. at 14 .

44 See Johnson, supra note 36, at 147. Part of the problem is that the US government, unlike European governments, has no official accreditation for ISO 9000 registrars, so that companies in other countries are less willing to accept the certifications of U.S. registrars. The National Institute of Standards and Technology is in the process of developing an official accreditation process that would meet at least the requirements for "regulated products." In addition, ISO itself has formed a group to develop a single, globally recognized registration system. Thurston, supra note 41 , at 12-14.

45 As noted above, many more European companies are certified to the standard, in part because of the relative ease and lower costs of accreditation. Only some 2,000 US companies have registered, compared with some 28,000 European ones. Businesses Get Chance to Participate in Development of New Environmental Management Systems Standards, PR NewswIRE, Oct. 7, 1994, available in LEXIS, World Library, CURNWS file.
} 
other areas will be merely guidance documents, ${ }^{46}$ and in part because the EMS standards have been on a fast track, since a global standard needed to be ready quickly to fit into the EMAS timetable. From 1992 through mid-1995, four large meetings and many more small ones took place to thrash out the content of an EMS standard. In June 1995, the technical committee approved a Draft International Standard for Certification, ISO 14001, and an accompanying guidance document on EMS, ISO 14004, and sent them out for voting to the entire ISO membership. If they are approved, the final standards should be in place by mid- or late $1996 .{ }^{47}$

\section{(ii) The Environmental Management System Standard}

Under the draft ISO EMS standard, an organization's environmental management system shall consist of an environmental policy defined by top management, which must include a commitment to continual improvement, to compliance with relevant law and other requirements, and to preventing pollution, and must contain a documented framework for setting and reviewing environmental objectives and targets. It shall include a

procedure to identify the environmental aspects of [the organization's] activities, products, and services that it can control and over which it can be expected to have an influence in order to determine those which have or can have significant impacts $\ldots$ and to ensure that the aspects related to these significant impacts are considered in setting its environmental objectives. ${ }^{48}$

The organization must then define environmental objectives, specific targets, and a management program. The management shall designate responsibility for achieving targets, and determine the means and time frames for both new and existing activities. ${ }^{49}$ Management is to provide human and financial resources essential to implementation, appropriate training, periodic monitoring, and corrective or preventive action in cases of nonconformance. ${ }^{50}$ The organization must also periodically audit its EMS performance, and top management must review the system's suitability and

46 The EMS Draft Standard states "[t]here is an important distinction between this specification which describes the requirements for certification/registration and/or self-declaration of an organization's environmental management system and a non-certifiable guideline intended to provide generic assistance to an organization for implementing or improving an environmental management system." INTERNATIONAL ORGANIZATION FOR STANDARDIZATION, Draft InTERnATIONAL Standard FOR Certification, ISO/TC 207/DIS 14001, Introduction (July 1995) [hereinafter Draft InTERnATIONAL StandARD 14001]. Later drafts include only editorial changes.

47 The two Draft International Standards have been approved in six months of balloting by member bodies, and then reissued for a 2-month joint ISO/CEN ballot. If at least two-thirds of all ISO members agree, and not more than a quarter vote against them, the standards will become final. The ISO standard will also be voted on as an American National Standard and, if approved, will simultaneously become the US and global standard. Id.
48 Id. 4.2.1.
49 Id. $4.2 .3,4.2 .4$.
$50 \quad I d .4 .3,4.4$ 


\section{I22 YEARBOOK OF INTERNATIONAL ENVIRONMENTAL LAW}

effectiveness. ${ }^{51}$ Each of these steps is specified and elaborated on in the specification document and, in greater detail, in the guidance document.

From the start, the debates over drafting the standard have revolved around the extent to which it would contain substantive, performance-based obligations or would be only a set of prescribed procedures and management techniques. A purely procedural approach allows maximum flexibility for management, but does not necessarily guarantee optimal environmental outcomes. ${ }^{52}$ It has the advantage of forcing organizations to engage in internal discussion before establishing goals and priorities, making it perhaps more likely that organizations will take the resulting plans seriously rather than seeking minimal or half-hearted compliance with externally-imposed rules. The danger is that because the goals and priorities are entirely selfchosen, they will only be implemented until changes no longer result in short-term cost avoidance or savings. Organizations will avoid investments requiring a longer investment horizon or that impose costs. Indeed, because compliance with local law is the only prescribed floor or minimum standard, companies that set and meet extremely lenient goals will conform to the standard to the same or greater extent than those companies that set more ambitious, and harder to realize, objectives.

As it now stands, the draft international EMS standard "does not establish absolute requirements for environmental performance beyond commitment, in the policy, to compliance with applicable legislation and regulation and to continual improvement." 53 An annex elaborates: "the rate and extent of [continual improvement] will be determined by the organization in the light of economic and other circumstances. ... The establishment and operation of an EMS will not, in itself, necessarily result in an immediate reduction of adverse environmental impact." 54

Disputes over procedure versus substance cropped up in several plàces. One of the most contentious involved the definition of "continual improvement" and whether evaluating the EMS would involve evaluating only improvements in the system itself, or also in its actual results. EMAS requires evaluation of a specified group of parameters, including resource use, waste avoidance, and the like. It then requires continual improvement of a participating site's actual performance in these areas. The United States and some other participants pushed for a definition of "continual improvement" that did not impose minimum rates of emissions or toxics reduction. European delegates, led by Austria, Denmark, Germany, and the United Kingdom, wanted language directly linking continual improvement with improvement in performance, not just of the system's operation.

The current draft specifies that continual improvement merely refers to "the process for enhancing the EMS to achieve improvements in overall
51 Id. 4.4.4, 4.5.
$52 I d$. at Introduction.
53 Id.

54 Id. at Annex A (Informative), A.4.0. 
environmental performance, in line with the organization's environmental policy. Note: The process need not take place in all areas simultaneously." 55 The tie-in between continual improvement and the organization's policy obtained the European delegates' agreement. But the definition of "environmental performance" is only the "measurable results of the EMS relating to an organization's control of the environmental aspects of its activities." An earlier draft made the difference clear: it defined performance as the "measurable outputs of the EMS, relating to an organization's control of the impacts of its activities ... on the environment." 56

Along similar lines, the United States and some other non-European delegations wished to limit evaluation of performance to conformance of the management system itself - did it operate as intended, were feedback loops operational, and the like-rather than of actual environmental performance. They argued that an international standard could not be dominated by the requirements of one region, and should focus on management systems, leaving performance to other regulatory tools and other parts of the standard-setting process. At the July 1995 meeting, compromise language was worked out that, according to at least some participants, clarifies that the draft EMS standard covers objectives and targets, and that continual improvement refers not only to refinements in the system itself, but to improvement of objectives and targets. ${ }^{57}$ While an improvement over prior drafts, the standard still leaves no way to judge whether the improvements are sufficient, and permits a company starting from a very low baseline to "improve" without ever meeting any international benchmark for adequate performance beyond compliance with local law.

Another aspect of this debate concerned the extent to which the standard would require a specific level of pollution control technology. At one point some European representatives pressed for a standard of "viable and

55 Id. 3.1 .

56 Benchmark Environmental Consulting/EEB, ISO 14001: An Uncommon Perspective: Five Public Policy Questions for Proponents of the ISO 14000 Series 15 (1995).

57 Interview with Dick Hortensius, Chief Negotiator of the Dutch Delegation, and Jose Cascio, Head of the US Delegation to TC 207, 18 INT'L ENV'T REP. (BNA) 555, 556 (1995). The changed wording comes in the definition section of the specification standard. The previous definition of "environmental management system" was "[t]he organizational structure, responsibilities, practices, procedures, processes and resources for implementing and maintaining environmental management." ISO/TC207/SC1/N 47, §3.6. In the July 1995 draft, the new definition read: "[t]hat part of the overall management system which includes organization, structural changing activities, responsibilities, practices, procedure, process and services for developing, implementing, achieving, reviewing and monitoring the environmental policy." The key change is the reference to policy at the end. The environmental policy section includes commitments to compliance, continual improvement, pollution prevention, and setting and reviewing environmental objectives and targets. Thus, at least according to some delegates, the policy becomes an auditable part of the EMS. InTERnational Environmental Systems Update, July 1995, at SB-27. However, this may be minimally useful, as attempts to extend audit requirements to objectives and targets failed. Id. at SB-33. 


\section{I24 YEARBOOK OF INTERNATIONAL ENVIRONMENTAL LAW}

achievable best available technology." 58 While such a standard might have little practical effect in much of Europe, where it would add little to existing laws, ${ }^{59}$ the US participants worried that in the United States it would change substantive legal requirements and could result in enormous civil and/or criminal liability. As a result, the standard's introduction merely provides that "the EMS should encourage organizations to consider implementation of best available technology where appropriate and where economically viable. In addition, the cost effectiveness of such technology should be fully taken into account." 60 It also specifies, in a late addition, that the standards "are not intended to be used to ... increase or change an organization's legal obligations." 61

The draft standard's definition of "environmental policy" does have some substantive components, but even these are limited. One requirement is "a commitment to comply with relevant environmental legislation and regulations, and with other requirements to which the organization subscribes."62 But organizations seeking certification presumably are already under a legal obligation to comply with local law; there is no additional requirement that, for example, an organization with operations in several countries apply the same rules, or the most stringent rules, to all its operations worldwide. ${ }^{63}$ The ISO definition of "organization" allows each operating unit of a corporation to be considered as a separate organization. This may be useful in ensuring that each operating unit must independently qualify for certification, but it also means there is no way to hold transnational firms operating in several countries to a higher standard than local law allows in each one. In contrast, several existing business codes of conduct call for global corporations to conform to home country standards wherever they

58 Interview with Christopher Bell, Sidley \& Austin, Member of the Technical Committee, in Washington, DC (Apr. 7, 1994). EMAS requires participating companies to aim at reducing environmental impacts to levels not exceeding those corresponding to economically viable application of best available technology. EMAS, supra note 23, Art. 3(a).

59 For example, German law has far-reaching duties requiring the imposition of the "state of technology" to control emissions. See Turner T. Smith Jr. \& Renne R. Falzone, Foreign Environmental Legal Systems: A Brief Review, 11 INT'L ENV'T REP. 621 (1988); see also Elli Louka, Bringing Polluters Before Transnational Courts: Why Industry Should Demand Strict and Unlimited Liability for the Transnational Movements of Hazardous and Radioactive Wastes, 22 Denv. J. INT'L L. \& Pol'y 63 (1993). In the United States, in contrast, most existing sources have to comply with less stringent technological requirements, at least for non-toxic pollutants. William Rodgers, Environmental Law 54-55, 228-29 (2d ed. 1994).

60 Draft InTERnATIONAL STANDARd 14001, supra note 46, at Introduction. The Introduction is not part of the specification part of the standard, but merely provides guidance.

61 Id at p. 1. This language is missing from the May $1994 \mathrm{draft}$.

62 The guidance annex specifies that "other requirements" may include industry codes of practice, agreements with public authorities, or non-regulatory guidelines. Id. at Annex, A4.2.2.

63 See, e.g., Alan Neff, Not in Their Backyards, Either? A Proposal for a Foreign Environmental Practices Act, 17 EcologY L.Q. 477 (1990). see also BENCHMARK Environmental Consulting, supra note 56, at 23-24. 
operate. ${ }^{64}$ Thus, as a tool for certifying environmental responsibility, the current draft international standard adds little.

The other substantive requirement worth noting is that the organization's environmental policy must include efforts at "pollution prevention." This language, inserted by the US delegation, is good in that it goes beyond compliance with existing laws and is in line with the thrust of much current thinking on environmental protection. But objections from some ISO delegations watered down the definition perhaps beyond the point of usefulness. At the July 1995 Oslo meeting, the definition was changed to include processes to control pollution, which may include recycling and treatment. ${ }^{65}$ According to the US EPA and many other experts, ${ }^{66}$ simple pollution control, after-the-fact treatment, and off-site recycling are not really prevention. Prevention focuses on changes in process, practices, and materials to avoid introducing pollutants into the environment at all.

A third area of debate concerned the specificity and public nature of requirements for evaluating environmental impacts. The original British standard that served as a model for the ISO draft contained a requirement for an "environmental effects register." Under the BSI 7750 standard, organizations must establish and maintain a register of significant direct and indirect environmental effects of activities, products, and services. ${ }^{67}$ While the purpose of an environmental effects register is to identify areas for improvement, US participants worried that in the US legal and regulatory climate, a document listing detrimental environmental impacts of corporate activity could be requisitioned by regulators or discovered in litigation, with disastrous consequences. ${ }^{68}$ The draft ISO standard thus contains no mention of an environmental register, only references to a "procedure to identify the environmental aspects of its activities, products and services that it can control and over which it can be expected to have an influence, in order

64 See, e.g., Business Charter on Sustainable Development, supra note 15; The Canadian Chemical Producers Association's Responsible Care guidelines also apply to worldwide operations. Benchmark Environmental Consulting, supra note 56, at 24.

65 It now reads: "Prevention of Pollution: Use of processes, practices, materials, or products that avoid, reduce or control pollution which may include recycling, treatment, process changes, control mechanisms, efficient use of resources, and materials substitutions." DRAFT INTERNATIONAL STANDARD 14001, supra note 46, at 3.14.

66 See US EPA, Policies for Pollution Prevention (1991); Rethinking the Materials We Use: A New Focus for Pollution Policy, supra note 3.

67 The register was to include, as appropriate, air and water emissions; wastes; land contamination; use of land, water, fuels, and energy and other natural resources; noise; visual impact; effects on specific ecosystems arising from both normal operations and accidents; and such information regarding future planned activities. BSI BS 7750, $\$ 4.4 .3$ and Annex A.4. As noted, EMAS requires similarly detailed evaluations.

68 Interview with Christopher Bell, supra note 58. Similar concerns were raised about requiring an audit verifying compliance with local laws. Committee Draft on Management Standards Addresses Pollution Avoidance Compliance, 18 InT'L Env'T DAILy (BNA), Mar. 8, 1995, at 175. Joe Cascio, head of US technical committee, says some US industry representatives were concerned that compliance audits might become public and be used for enforcement purposes. 


\section{I26 YEARBOOK OF INTERNATIONAL ENVIRONMENTAL LAW}

to determine those which have or can have significant impacts on the environment." 69 The organization need only "consider" the aspects related to these significant impacts in setting objectives and targets. An annex specifies air emissions, releases to water, waste management, and the like as possible environmental aspects, but contains nothing mandatory, leaving it up to each organization to consider such parameters "where appropriate."70

Furthermore, the procedure, and its results, need not be made public. The United States argued that requiring environmental policies and objectives to be publicly available would discourage companies from setting ambitious, meaningful objectives rather than listing vague platitudes..$^{71}$ European representatives, on the other hand, argued that credibility depended on making at least basic information publicly available. In addition, EMAS requires public disclosure, and the external pressure presumably generated by such disclosure is considered central to its effectiveness. ${ }^{72}$ The draft standard does require the organization's environmental policies to be publicly available. But on the more important issue of environmental impacts, it requires only that "the organization shall consider processes for external communication on significant environmental aspects of its activities and record its decision." 73

69 Draft InTERnational Standard 14001, supra note 46, at 4.2.1.

70 Id. at Annex, A4.2.1.2. Those parameters are to be systematized and harmonized through the work of the Environmental Performance Evaluation (EPE) subcommittee of TC 207, expected to be ready by 1998. EPE is a "process to measure, analyze, assess, and describe an organization's environmental performance against agreed criteria for appropriate management purposes." It defines a system for measuring and reporting performance improvements such as units of measurement and base time periods.

Originally, the subcommittee divided into working groups on generic and sector-specific EPE. The Europeans, especially the Norwegians, pushed for a standard that would specify, for some 5-10 priority industry sectors, maximum allowable emissions of key pollutants. Christopher Bell \& James Connaughton, New Global Standards May Guide Industry on Environmental Issues, NAT'L L.J., Sept. 6, 1993, at S4. Others, including the United States, considered the effort as too ambitious and too fraught with difficulties stemming from regional and local variation. They wanted more general criteria, to be used primarily as internal evaluation tools. The United States position prevailed: as of April, 1994, development of industrial sector indicators was abandoned, and the EPE group reconfigured into working groups on management system EPE and operational system EPE. The operational system EPE is to develop a series of diagnostic tools for measuring environmental performance. These will include such measures as quantity per unit of production of effluents, emissions, and wastes; changes in output over time; and compliance record. Companies will be free to pick and choose among the indicators, however, none will be required.

71 See Bell \& Connaughton, supra note 70.

72 Caroline London \& Brizay London, Disclosure Obligations and Due Diligence Practices in Europe, C764 A.L.I.-A.B.A. 667, 670-71, Sept. 24, 1992, (discussing EC Directive of June 7, 1990, requiring freedom of access to information on the environment); European Community: Business Warned of More Disclosure, Environmental Audits in Europe, DAILY INT'L EnVtl. ReP. (BNA), April 22, 1992. Also, Article 5 of EMAS requires a published environmental statement, including a summary of data on emissions, wastes, consumption of raw materials and energy, and other factors. EMAS, supra note 23.

73 Draft InTERnATIONAL STANDARD ISO 14001, supra note 46, at 4.3.3. Communication with stakeholders is also limited: when establishing its objectives, an organization is to consider the 
The reach of the ISO standards is more limited than that of EMAS. EMAS requires firms to "ensure that suppliers and those acting on the organization's behalf comply with the company's environmental policy as it relates to them." 74 The draft ISO 14000 standard is more vague as to the registered companies obligations, requiring only "communication of relevant procedures and requirements to suppliers and contractors." 75 The idea that ISO-certified companies might require outside parties to meet any similar requirements was specifically rejected. ${ }^{76}$

A final area of controversy concerned the relationship between the EMS and environmental audits. ${ }^{77}$ EMAS requires a public statement, contains detailed requirements for audits, and requires the use of an external verifier. ${ }^{78}$ The audit required under EMAS covers not only the management system, but also the data on environmental performance. Here again, European participants maintained that a system of audits that included independent audit verification and publication of at least a summary of audit results was necessary for both credibility and real pressure for improvement. Other delegations, led by the United States, found the costs of third-party verification excessive and often unnecessary, ${ }^{79}$ especially after the US experience with quality control, where verifiers had to be hired from Europe. ${ }^{80}$ In the end, the US position prevailed. The Draft International Standard for Certification requires only an internal audit of the management system itself, to determine whether it conforms to the standard and

views of interested parties, but it is unclear on the basis of what information such parties are to form their views, or to what extent companies must act on the views expressed. Id. at 4.2.3.

74 EMAS, supra note 23, at Annex I, 4(b).

75 DRAFT INTERNATIONAL STANDARD 14001, supra note 46, at 4.3.6.(c) is entitled "control procedures for routine operations." It requires the organization to "establish and maintain procedures related to the significant environmental aspects of goods and services used by the organization and communication of relevant procedures and requirements to suppliers and contractors." Elsewhere, the Annex warns that "[t]he control and influence over the environmental aspects of products vary significantly, depending on the market situation of the organization." Id. at Annex A4.2.1.

76 International Environmental Standards Update, supra note 57, at SB-32.

77 A separate subcommittee within TC 207 is developing specific auditing standards. Detailed procedural requirements for audits are laid out in separate draft standards dealing with general audit principles (ISO 14010), auditing of environmental management systems (ISO 14011/1) and qualification criteria for environmental auditors (ISO 14012), all of which were approved as draft international standards in July 1995. They deal with such issues as periodicity of audits, confidentiality of audit results, appropriate training for auditors, and the like. Other auditing standards on compliance/performance audits and auditing of environmental status were deleted, while a new proposal for environmental site assessments was to be decided on in 1997. Draft International 14000 Series Standards-Document Status, QuALITY Systems Update, Special Report, July 1995, at R-4.

78 EMAS, supra note 23, Art. 4.3, Annex 2.

79 By one estimate, third-party certification had added $20 \%$ to the cost of registration with the ISO 9000 standard. Joe Cascio, International Environmental Management Standards, ASTM Standardization News, April 1994, at 45.

80 See supra note 44 and accompanying text. 
has been properly implemented and maintained. ${ }^{81}$ It also requires a management review to ensure the "continuing suitability, adequacy and effectiveness" of the EMS. ${ }^{82}$ The audit is designed to serve a strictly internal function. The organization may decide whether the audit is to be internal or external, and there is no obligation to make the audit results public.

In all these instances, the main lines of debate pitted European participants against a "rest-of-the-world" camp led by the United States. Domestic considerations largely drove both sides. The US position was generally to seek less substantive, more procedural and flexible positions that preserved management prerogatives and corporate secrecy. ${ }^{83}$ European representatives wished to ensure that compliance with the ISO standard would also constitute compliance with the EMAS regulation, ${ }^{84}$ which imposed several more substantive obligations, as did existing national European standards. Countries worried about the possible trade-restrictive or competitiveness effects of substantive standards tended to support the US delegation. This included many developing-country delegations.

In addition to the European imperative to make the standard acceptable to the European Commission for EMAS purposes, many of the differences originated in divergent legal cultures and norms between Europe and the United States. In Europe, discovery rules are more protective, ${ }^{85}$ and the threat of large-scale liability or criminal prosecutions is more remote. ${ }^{86}$ There is no Europe-wide enforcement agency equivalent to the US EPA, and national enforcement of environmental law varies greatly among European states ${ }^{87}$ Regulatory compliance and liability concerns drive the move toward environmental management and auditing standards in the United States, while proving that a company is "green" is a more salient motivator in Europe. ${ }^{88}$ Moreover, many companies in the United States have been in the forefront of recent efforts to shield the results of voluntary

81 Draft InTERnAtional Standard 14001, supra note 46, at 4.4.4.

82 Id. at 4.5 .

83 Some of these debates are described above. On the other hand, the US delegation was responsible for inserting language requiring efforts at "pollution prevention" by all organizations seeking certification. See supra note 65 and accompanying text.

84 International Environmental Management Standards, ISO/TC 207, Update (May 1994) (on file with author). See supra notes $72-78$ and accompanying text.

85 See, e.g., Louka, supra note 59; see also Peter Roorda, The Internationalization of the Practice of Law, 28 WAKe Forest L. Rev. 141 (1993).

${ }^{86}$ See, e.g., Barbara A. Boczar, Toward a Viable Environmental Regulatory Framework: From Corporate Environmental Management to Regulatory Consensus, 6 DEPAUL Bus. L.J. 291 (1994); Gert Bruggermeir, Enterprise Liability for "Environmental Damage" in German Law and EC Law, 2 New Eur. L. Rev. 17 (1994).

87 See James E. Pfander, Environmental Federalism in Europe and the United States: A Comparative Assessment of Regulation Through the Agency of Member States, in Environmental Policy with Political and Economic Integration 59, 72 (John B. Braden et al. eds., 1995).

88 See Linda Spedding, Environmental Auditing and International Standards, 3 REv. EuR. Community \& INT'L ENVTL. L. 14, 15 (1994). 
environmental audits from public and regulatory scrutiny, and were not about to let international standards undermine their domestic positions. ${ }^{89}$ Finally, as discussed below, the especially corporate-heavy nature of the US delegation to ISO may explain some of the positions taken.

\section{PRODUCT STANDARDS AND ECO-LABELLING}

The EMAS and ISO 14000 approaches focus on organizations and their production processes, seeking to gather information on the impacts generated during the production and distribution cycle of any number of products. In contrast, the eco-labelling approach begins with the product itself, looking at the environmental impacts of a particular product from "cradle to grave"-production, distribution, use, and disposal. It attempts to create economic incentives for products with less environmental impact by providing information to consumers.

\section{A. Eco-Labelling and Life-Cycle Assessment Standards}

Eco-labelling programs now exist in at least 11 countries as well as the EU and the Nordic Council..$^{90}$ Examples are Green Seal and Green Choice in the United States and Blue Angel in Germany. In March 1992, the EC Council passed a regulation setting up a Community eco-label for environ-

89 Industry representatives are now attempting to have information generated in the process of conducting a very broadly defined "environmental audit" declared confidential. Under heavy corporate pressure, seven states have enacted legislation creating a broad "self-evaluative" privilege for anything termed an audit report, while 21 others have legislation pending. More States Adopt Audit Privilege Laws; EPA Calls Federal Legislation Ill-Advised, 25 Env'T REP. (BNA) 2186 (1995). A proposed federal Environmental Audit Protection Act would allow any document labeled an "environmental audit report" or its supporting documentation to be kept confidential. The theory is that if regulators or the public could obtain information contained in an audit that was not required under the law, the thoroughness of the audit would suffer. Opponents respond that unscrupulous corporations will be able to cover almost anything, including evidence of legal violations, under the rubric of an "environmental audit report," and will use the audit process strategically to disclose some violations but not others. Under EPA's current audit policy, EPA will not routinely request access to a firm's audits in the course of enforcement activities, but reserves the right to demand access to audits on a case-by-case basis. US EPA, Restatement of Policies Related to Environmental Auditing 4 (1994), reprinted in 59 Fed. Reg. 38455 (July 28, 1994). The current ISO draft environmental audit standards neither require nor forbid publication of audit results by the client, although they do require the auditee's permission where the client and auditee are different. International Organization for Standardization, Draft Guidelines for Environmental Auditing, Auditing of Environmental Management Systems, ISO/TC207/SC2/N64 at 5.4.3 (1995). For a fuller discussion, see Sanford Lewis, Corporate Environmental Audits and the Public's Right to Know (Feb. 1, 1995) (unpublished report, on file with author); David Ronald, The Case Against an Environmental Audit Privilege, 29 Chemical Waste Litig. Rep. 167, 168-69 (1995); No Audit Privilege in Interim EPA Policy; Lack of Prosecution, Punitive Fines Possible, 25 Env't ReP. (BNA) 2411 (1995).

90 Programs exist in Austria, Canada, Denmark, France, Germany, Japan, the Netherlands, New Zealand, Singapore, and the United States. 


\section{I30 YEARBOOK OF INTERNATIONAL ENVIRONMENTAL LAW}

mentally superior goods. ${ }^{91}$ The EC has developed criteria for labelling certain consumer durables like washing machines and dishwashers, ${ }^{92}$ as well as for toilet paper, paper kitchen towels, soil improvers, and laundry detergents. ${ }^{93}$

Most eco-labelling programs are sponsored by government agencies, ${ }^{94}$ although in the United States only non-governmental programs exist. The most prevalent are programs that give seals of approval to products that meet a set of criteria regarding the product's overall environmental impact. The groups awarding these labels recognize the subjective nature of the weights assigned to different measures of environmental superiority; therefore they rely on advisory boards or other groups to make the judgments involved. ${ }^{95}$ Certifiers typically grant seal-of-approval labels to only the top $10-15 \%$ of products in a given field, hoping that the seal or label will provide such industry leaders with a marketing edge that the rest of the industry will want to emulate. ${ }^{96}$ Manufacturers pay to have their products

91 Council Regulation No. 880/92 of March 23, 1992, on a Community eco-label award scheme, published in 1992 OJ L 99 (April 11, 1992). The scheme is intended to promote the design, production, marketing, and use of products that have a reduced environmental impact during their entire life cycle. Specific ecological criteria for each product group (defined as products that serve similar purposes and that have equivalent uses) are to be defined by the Commission in consultation with Community-level representatives of industry, commerce, consumer, and environmental organizations. Manufacturers or importers will then apply to "competent bodies" to be designated within each member state, who will decide if the eco-label will be awarded. The general list of criteria annexed to the regulation is based on product life-cycle analysis.

92 93/430/EEC: Commission Decision of 28 June 1993 establishing the ecological criteria for the award of the Community eco-label to washing machines; 93/431/EEC: Commission Decision of 28 June 1993 establishing the ecological criteria for the award of the Community eco-label to dishwashers, both published at 1993 OJ L 198 (Aug. 7, 1993). The eco-label is to be awarded on the basis of meeting minimum performance standards for energy use, water use, and recyclability of certain plastic parts.

93 Eco-labelling work starts on seven new product groups, ENDS REP. 247, Aug. 1995, at 28. The criteria for soil improvers and paper products have been highly controversial, and proposed criteria for paints and varnishes have yet to be approved by the Commission. To date, only one manufacturer, Hoover, has received an EC eco-label for its products. Id.

${ }_{94}$ For example, the German Blue Angel program has since 1978 operated as a joint effort of the German Federal Ministry of the Environment, the German Institute for Quality Control and Labelling, and a representative non-governmental Environmental Labelling Jury. GARY A. Davis, The Use of Life-Cycle Assessment in Environmental Labelling Programs 17 (1993) (prepared for Pollution Prevention Division, Office of Pollution Prevention and Toxics, US EPA). The French program is run by the national standards organization, while the Dutch eco-label, although administered by a non-governmental foundation, is financed by the government. $I d$. at 20, 21. The Singapore Green Labelling Scheme is administered by the Ministry of the Environment, while the Japanese Eco-Mark Program operates under the guidance of the National Environment Agency. Id. at 34, 36.

95 For a description of the US Green Seal, see Roger D. Wynne, The Emperor's New EcoLogos?: A Critical Review of the Scientific Certification Systems Environmental Report Card and the Green Seal Certification Mark Programs, 14 VA. EnvTL. L.J. 51, 83-93 (1994).

96 Interview with Arthur Weissman, Green Seal, in Washington, DC (April 6, 1994); see also Norman L. Dean, Testimony ... Before the Federal Trade Commission on Issues Relating to Environmental Marketing and Advertising Claims and Pending Petitions for Interpretive Guides 5 (July 17, 1991); Norman L. Dean, Life-Cycle Review as a Tool in Standard-Setting, in Rethinking the Materials We Use: A New Focus for Pollution Policy 47, 50, supra note 3; Wynne, supra note 95 , at 88 . 
evaluated for compliance with the specifications, and, if they pass, receive the right to display an eco-label and use it in advertising. ${ }^{97}$

To date, the different programs share no common criteria or methodology. A recent US EPA study showed that although the different national programs address the same general environmental issues and the same product categories, they use very different methodologies and parameters to establish an acceptable level of environmental benefit. ${ }^{98}$ Even when producers refer to only one attribute of a product-its recyclability, for example - the word means different things in different places and according to different manufacturers.

One way to decide whether a product has superior environmental attributes is to perform some version of a life-cycle analysis (LCA). LCA tries to evaluate and quantify the environmental impacts of a product from inception to disposal. ${ }^{99}$ According to the US EPA, it consists of three steps: inventory analysis, impact analysis, and improvement analysis. ${ }^{100}$ There is some emerging consensus as to the first step, which is to identify and quantify resource use and environmental releases in common units, using a common data-gathering methodology. ${ }^{101} \mathrm{~A}$ common approach to using such an inventory to evaluate overall environmental effects is still in its infancy. There is no generally accepted methodology. Especially problematic is the valuation of different types of impacts in relation to each other, which depends in large part on social and cultural values and preferences. ${ }^{102}$ So too is the determination of boundaries - whether, for instance, LCA should also consider the manufacture of component parts or energy generation in evaluating impacts. ${ }^{103}$ In addition, LCA analysis is very expensive and time

97 Kristin Dawkins, Ecolabelling: Consumers' Right to Know or Restrictive Business Practice?, Institute for Agriculture And Trade Policy, Sept. 1995, at 3.

98 DAvis, supra note 94 , at 38-40.

99 US EPA Risk Reduction EngineEring Laboratory, Life-Cycle Assessment: InVENTORY Guidelines AND PRINCIPLEs 98-99, EPA/600/R-92/245 (1993).

100 Some practitioners add a fourth step, the scoping and goal definition, or initiation step. For a fuller description, see Society of Environmental Toxicology and Chemistry, A Technical Framework for Life-Cycle Assessments (1991); US EPA Risk Reduction ENGINEERING LABORATORY, supra note 99.

101 US EPA RISK REDUCTION ENGINEERING LABORATORY, supra note 99.

102 Davis, The Use of Life Cycle Assessment in Environmental Labelling Programs, supra note 94, at 4-6. LCA has to date proven quite sensitive to small changes in assumptions and categories of analysis. For example, LCA studies on the relative impacts of different bottling methods, or of cloth versus paper diapers, have come to differing conclusions. See, e.g., Peter S. Menell, Eco-Information Policy: A Comparative Institutional Perspective, John M. Olin Program in Law and Economics Working Paper No. 104 34-36 (1993). Menell describes how two studies (commissioned respectively by the diaper services industry and the disposable diaper makers) came to dramatically different numbers in estimating such variables as the water consumption of cloth diaper services. While both considered a similar range of impacts, they reached different conclusions on many of them.

103 See US EPA Risk Reduction EngINEERING LABORATORY, supra note 99. In addition, effects such as habitat modification, thermal pollution, and noise pollution are not easily amenable to quantification for inventory purposes. For more on the limits of LCA, see Mary 


\section{I32 YEARBOOK OF INTERNATIONAL ENVIRONMENTAL LAW}

consuming. For these reasons, most eco-labelling programs use only a limited form of LCA, focusing on one or two product attributes and limited boundaries. ${ }^{104}$

The difficulties with LCA and eco-labelling become more salient on the international level because of differing environmental contexts and degrees of development. The first key issue is deciding which categories of impacts to inventory. For example, in sparsely populated, arid areas, water use and conservation may be an important characteristic, whereas in a relatively wet, densely populated area it might be unimportant.

Determining which of the inventoried impacts to stress is also problematic. For example, a standard that favors recycled paper over farmed pulp may be appropriate in a densely populated, technologically advanced society, but not in an agricultural country with abundant land and less ability to manage the toxic wastes that result from the recycling process. ${ }^{105}$ Another question might be whether global and local impacts should receive the same weight or whether global impacts like ozone loss or climate change should be stressed. Other issues include categorization of emissions and choice of units (e.g., absolute or relative to a threshold of potential harm). Finally, LCA is at present very expensive, and probably beyond the reach of small and medium producers. Any requirement to implement a full LCA, at this point, favors larger producers.

The proliferation of groups and of unsubstantiated claims of environmental friendliness has led to increasing calls for order among both producers and consumers. ${ }^{106}$ The labelling programs themselves have responded by creating a forum for harmonization of criteria. ${ }^{107}$ In addition, ISO's TC 207 has created subcommittees on both eco-labelling and LCA. ${ }^{108}$

The ISO Sub-Committee on Environmental Labelling has, as of this writing, focused on producing three guidelines: a general document on Goals

Ann Curran, Broad-Based Environmental Life-Cycle Assessment, 27 EnvTl. SCI. \& TeCH. 430, 433-35 (1993).

104 Davis, The Use of Life Cycle Assessment in Environmental Labelling Programs, supra note 94 .

105 In the European eco-labelling context, Brazil objected to the criteria for paper products on these grounds, among others. Dawkins, supra note 97, at 55.

106 See George Richards, Environmental Labelling of Consumer Products: The Need for International Harmonization of Standards Governing Third-Party Certification Programs, 7 Geo. INT'L ENVTL. L. REv. 235 (1994).

107 Interview with Valerie Douglas, Green Seal Vice-President of International Standards, in Washington, DC (April 6, 1994).

108 The LCA subcommittee is still in the early stages of developing drafts on principles and guidelines and on inventory analysis, impact assessment and improvement assessment (now termed "interpretation.") Progress has been hampered by the uncertain state of the underlying science, and overall rules are several years away. Other issues raised by the LCA subcommittee include differences between "in-house" LCA analysis and that done for purposes of comparing one's product to that of others, known as "comparative assertions." The draft proposal includes additional requirements to use the results of LCA for comparative purposes. 
and Principles of All Environmental Labelling ${ }^{109}$ and more specific guidelines for multiple-criteria "practitioner" programs ${ }^{110}$ and self-declaration environmental claims. ${ }^{111}$

One early debate over the labelling standard concerned its ultimate goal. While professional labelling practitioners from groups like Green Seal and Blue Angel stressed environmental improvement through market mechanisms as the goal, most corporate participants have favored an emphasis on simply providing consumers with accurate information. ${ }^{112}$ An early draft of the Goals and Principles document clearly spelled out the goal of labelling as improving the environmental performance of products and services, but by August 1995, the section on goals had become a general introduction that was not even technically part of the standard. It affirmed that:

the overall goal of the ISO 14000 series is to lessen the stress placed on the environment by the production, use and disposal of products and services. . . The use of environmental labels/declarations, based on accurate, non-deceptive and verifiable information, contributes to this overall goal by stimulating the potential for market-driven continuous environmental improvement.

The November 1995 meeting rejected this language too, and a revised goal statement referencing environmental improvement is now part of the draft standard again. But the debate over goals continues.

The draft principles require environmental labels/declarations to be accurate, verifiable, relevant, non-deceptive, and based on scientific methodology. Further, they must not inhibit innovation. While they should,

109 International Standardization Organization, Goals and Principles of All EnVIronmental LABELING, Committee Draft ISO 14020 (July 1995).

110 International Standardization Organization, Environmental LabellingPractitioner Programs-Guiding Principles, Practices and Certification Procedures of Multiple (Type I) Programs, Committee Draft 14024, (July 1995). In the ISO terminology, Type I labels are "multiple criteria-based third party" or "seal-of-approval" labels given to products that meet a set of criteria regarding the product's overall environmental impact. The subcommittee's draft standard for Type I programs failed to win sufficient support in July 1995 to be advanced to draft international standard status, and a new vote was expected by early 1996.

Type II labels are "self-declaration claims," discussed below. A Type III label does not try to evaluate overall impact, but simply reports the findings of an independently conducted lifecycle assessment under a set of pre-established indices. While standards for Type III labels were part of the 1993 work plan, work never began because too few of these programs existed worldwide. A new work item on Type III labelling will probably come forward in 1996. QUALITY SYSTEMS UPDATE, supra note 77, at SR-4.

111 International Standardization Organization, Self Declaration Environmental Claims-Terms and Definitions, Committee Draft ISO 14021 (1996). These are singleattribute claims made by manufacturers, without independent third-party certification, for such qualities as recycled content and compostability. They may take the form of statements, symbols, or graphics on product or package labels, advertising, etc.

112 TC207/SC3/WG3 correspondence, May-June 1994 (on file with author); interview with participants, Dec. 1995. 


\section{I34 YEARBOOK OF INTERNATIONAL ENVIRONMENTAL LAW}

"wherever appropriate, take ... [] into consideration the life cycle of the product or service," there is no obligation to base labelling decisions on LCA. The principles require information to be provided to purchasers on the meaning of any claims, symbols, or other environmental attributes. Any concerned party is entitled to information about the procedures and methodology used to support the label. To protect against unfair advantages for large producers, the principles require administrative requirements or information demands to be limited to those necessary to establish conformance, and not to entail unnecessary cost or administrative complexity.

Another debate concerns the degree of consensus necessary to arrive at appropriate standards and criteria. While all participants agreed that all stakeholders should have input into the process, those involved in administering seal-of-approval programs argued that requiring full consensus of all interested parties was impossible. Moreover, they argued, the criteria for granting labels would be undesireably watered down if producers unable to comply with stringent requirements could block a consensus decision. An early draft, therefore, required only that the decision-making process be "transparent to all potentially affected parties." 113 By August 1995, however, corporate pressure had transformed that language into a requirement that standards and/or criteria "be developed through a consensus process." 114

\section{B. Eco-Labelling and International Trade Concerns}

The draft principle dealing with the potential use or misuse of eco-labels as barriers to trade has proven the most controversial. It involves two intertwined issues: the extent to which ISO institutionally had the ability to propose rules in an area where trade, development, and environment

113 ISO TC 207/SC3/WG3/Draft 2, Apr. 14, 1994, principle 5. In the more specific guidance document on "multiple criteria-based practitioner programs," transparency requires only "the clear and 'open-for-examination' availability of the rationale and details on which the programme is based, as well as availability for inspection and comment of other relevant information. Guiding Principles, Practices and Criteria for Multiple Criteria-Based Practitioner Programmes Guide for Certification Procedures, Working Draft ISO/WD 14024.2, ISO/TC 207/SC 3/WG1/N 43, Sept. 1995, at 4.8. Participation or consensus among stakeholders is not mentioned.

114 ISO/TC 207/SC3/N 64, Principle 9. The explanatory text specifies:

[t] he process for developing standards and criteria shall be open to all interested parties. The parties shall be invited to participate and encouraged to become involved through timely and adequate notification. Parties may choose to participate directly or through other means such as written or electronic correspondence. Comments and input shall be responded to in a meaningful way that addresses the substance of the comment or input. For further guidance see ISO guides 2 and 59.

Those ISO guides define consensus to mean less than $100 \%$ agreement, but basic agreement among all major affected parties-leaving some room for a standard to be approved over the objections of one or more interests. Telephone Interview with Arthur Weissman, Green Seal (Dec. 11, 1995). 
organizations are already actively working, ${ }^{115}$ and the content and specificity of any ISO 14000 principle on the subject.

Eco-labelling has been particularly vulnerable to accusations that national programs in effect discriminate in favor of domestic producers. For example, eco-labelling criteria may reflect domestic perceptions of environmental problems and their solutions, ignorance of "low-tech" alternatives to environmentally destructive practices, ${ }^{116}$ or high testing and certification costs for small producers, especially in poor countries. ${ }^{117}$

GATT dispute resolution panels have on at least two occasions referred to voluntary labels as permissible, and indeed preferable, strategies for protection of health and the environment. ${ }^{118}$ Mandatory labelling schemes are more ambiguous. One the one hand, in the Thai Cigarette case a dispute settlement panel indicated that a "non-discriminatory regulation implemented on a national treatment basis" requiring label disclosure of cigarette ingredients would be consistent with GATT.119 On the other, a 1991 Austrian eco-labelling scheme was widely criticized as being inconsistent with GATT. Austria had enacted an ecolabelling law on tropical timber in an effort to use consumer pressure to improve timber-harvesting practices. ${ }^{120}$ The law required labelling of all tropical timber and created a "quality mark" for timber from sustainable harvesting sources. It also increased import tariffs on tropical timber and used the resulting revenues to promote sustainable harvesting of tropical timber. ${ }^{121}$ Malaysia, Indonesia, and other producers of tropical timber promptly protested the

115 The World Trade Organization's Committee on Trade and Environment has taken up eco-labelling as part of its work programme. WTO SECRETARIAT, REPORT OF THE MEETING HELD 16 FeB. 1995, WT/CTE/M/1, (Mar. 6, 1995). OECD, the United Nations Commission on Trade and Development, and the United Nations Environment Programme are all considering some aspect of eco-labelling or related issues. Dawkins, supra note 97, at 11 and $\mathrm{nn} .30-34$.

116 For example, the use of natural dyes rather than more environmentally friendly chemicals in textiles, or the switching to use of jute or hemp instead of trying to make improvements in the creation of plastic-based products.

117 See Dawkins, supra note 97, at 4-8; Laura B. Campbell, United Nations Environment Programme, International Environmental Standards: Their Role in Mutual ReCOGNITION OF ECOLABELling SCHEMES (1994).

118 In the Tuna-Dolphin I case, the panel upheld provisions of the US Dolphin Protection Consumer Information Act because the labelling law was voluntary and did not confer a government advantage. Paras. 5.41-5.42. GATT, United States-Restrictions on Imports of Tuna (Sept. 3, 1991), Panel Report No. DS21/R, reprinted in 30 I.L.M. 1594. The case concerned provisions of the US Marine Mammal Protection Act that prohibited imports of tuna from countries that failed to take sufficient measures to ensure the safety of the dolphins that swim with schools of tuna.

119 In that case, the panel recommended a label on cigarette packages as a less trade-restrictive, and therefore preferable, alternative to prohibitions on cigarette imports for health reasons. GATT, Dispute Settlement Panel Report on Thai Restrictions on Importation of and Internal Taxes on Cigarettes (Nov. 7, 1990) 30 I.L.M. 1122 (1991), at para. 77.

120 Brian Chase, Tropical Forests and Trade Policy, 17 Hastings Int'L \& Comp. L. Rev. 349, 375 (1994).

${ }_{121}$ Id. 


\section{I36 YEARBOOK OF INTERNATIONAL ENVIRONMENTAL LAW}

measure under the Technical Barriers to Trade Agreement, arguing that it was a discriminatory non-tariff barrier. ${ }^{122}$ Part of the problem under GATT was that the measure applied only to tropical timber, not all timber. Another problem was that there is no internationally agreed upon definition of "sustainably harvested timber." ${ }^{123}$ No dispute settlement panel was ever convened. In response to Malaysia and other Asian governments' threats to retaliate, Austria backed down.

The European eco-label has also created controversy, as qualifying goods must meet all EC health, safety, and environmental regulations during production. ${ }^{124}$ Many non-European companies have criticized this requirement as a trade barrier; indeed, one of the impetuses behind the ISO effort in this area is to create conditions for mutual recognition of programs with equivalent, but not identical, criteria. ${ }^{125}$

An early version of the ISO eco-labelling standard simply noted that "environmental labelling should be non-discriminatory in its treatment of domestic and foreign products and services." ${ }^{126}$ As ISO participants learned more about the complexity of the trade and environment issue, that fairly uncontroversial statement expanded into a detailed, three-part statement of possible trade barriers, permissible restrictions, and ways to avoid potential conflicts. ${ }^{127}$ As the language became more complex and debated, many par-

122 Austrian Industry, Malaysians Angered over Tropical Wood Labelling Requirement, INT'L ENv'T DAILY (BNA), Nov. 16, 1992, available in LEXIS, Intlaw Library, BNAENV file.

123 The Forest Stewardship Council, set up in October 1993, is an attempt to set global standards for good forest management and provide accreditation for organizations offering certification schemes for timber. See George Richards, Environmental Labelling of Consumer Products: The Need for International Harmonization of Standards Governing Third-Party Certification Programs, 7 Geo. InT'L EnvTL. L. REv. 235, 245 (1994).

124 Council Regulation No. 880/92, supra note 91, Art. 4.1.

125 See generally Rene Vossenaar \& Veena Jha, PPMs and Developing Countries, in Organization for Economic CoOperation and Development, Trade and Environment: Processes and Production Methods 137, 144-5 (1994). There is, however, considerable resistance to including detailed references to mutual recognition or equivalence in the standard itself, because it is unclear exactly what would be entailed. JAMES CONNOUGHTON, SC 3, REPORT TO THE US TAG, TC 207, San Francisco, California (Apr. 18, 1996).

126 TC 207/SC 3/WG 3/Draft 2/ Goals and Principles of All Environmental Labelling, Apr. 14, 1994, at principle 8 . The supporting text elaborated that:

[t]he principle of "non-exclusivity" should be applied in general to avoid the exclusion of products or manufacturing processes otherwise recognized as legitimate ones. Criteria may de facto exclude certain foreign producers because of their infringement of a basic environmental principle (for example, use of endangered species products), but the restriction should not be based on the fact that the producers are foreign. . . "Regulatory equivalence" procedures should be provided in order to resolve an otherwise discriminatory situation.

127 The August 1995 draft, ISO/TC 207/SC3/WG3/N64, at principle 7 reads:

instances of potentially unfair trade barriers include, but are not limited to, the following:

- requirements to meet specific national or local legislation, regulations, or standards rather than performance objectives;

- restrictions on testing methods such as the following:

requiring national or local procedures rather than an internationally accepted testing or assessment method or an industry/trade test which has been subjected to peer review; 
ticipants began to fear that the ISO eco-labelling guidelines would be inconsistent with the work being carried out in other fora, especially the WTO's Committee on Trade and Environment. Although some developing countries were in favor of spelling out potential barriers to trade, as of December 1995 the language was again reduced to a minimal prohibition on discrimination against foreign producers, with a reference to the WTO for further information. ${ }^{128}$ While this outcome seems correct in that ISO is an inappropriate forum for developing new rules in this highly contested area, it is unfortunate that the draft standard refers only to the WTO, ignoring other international organizations including the United Nations Environment Programme and the United Nations Committee on Trade and Development, which are also working on the trade and environment issue.

- restrictions on the recognition of testing facilities which could create an impossible geographic requirement;

- language requirements related to the transmission of data and performance attributes;

- inequitable application of costs, fees, charges, or requirements;

- administrative requirements which limit access by foreign producers to activities or programs related to environmental labels/declarations or their ability to comment on the development of criteria for environmental labels/declarations;

- requirements to conform with nationally developed technologies or manufacturing processes.

There may be instances in which trade restrictions against certain products or services are legitimate. These include, but are not limited to, the following:

- items covered by international conventions and treaties, such as ozone-depleting substances, endangered species, etc.;

- products or services which current scientific data show to have a harmful effect on the environment or public health of the country that is imposing the restrictions;

In order to foster international harmonization in environmental labels/declarations and reduce any potential to unduly restrict trade, the following are recommended objectives:

- recognition of environmental improvements in different countries as potentially equivalent based on their overall purpose and significance, even if the improvements are different in nature (e.g. aspect of environment affected)

- mutual recognition among environmental labels/declarations based on equivalency of procedure, criteria, and objectives.

128 It now reads: "Procedures and requirements for environmental labels/declarations shall not be prepared, adopted, or applied with a view to, or with the effect of creating unnecessary obstacles to international trade. Note: For guidance on the above principle, the provisions and interpretations of the WTO should be taken into account." ISO/TC 207/WG 3 meeting minutes, Seoul, Korea, Nov. 30, 1995 (on file with author). The language tracks exactly the formulation in the Code of Good Practice, which is Annex 3 to the GATT's Technical Barriers to Trade Agreement, discussed in greater detail infra at note 191. Final Act Embodying the Results of the Uruguay Round of Multilateral Trade Negotiations, Agreement on Technical Barriers to Trade, April 15, 1994, reprinted in H.R. Doc. No. 316, 103d Cong., 2d Sess. 1428 (1994) [hereinafter TBT Agreement]. The interpretative "note" regarding the WTO barely passed by a vote of 11 to 8 , with two abstentions. 
I38 YEARBOOK OF INTERNATIONAL ENVIRONMENTAL LAW

\section{PRIVATE VOLUNTARY STANDARDS AND THE MAKING OF INTERNATIONAL ENVIRONMENTAL LAW}

\section{A. A Transnational Drafting Process}

Unlike prior ISO technical standards, or even quality assurance rules, the environmental management, life-cycle, eco-labelling, and related standards affect constituencies, both human and non-human, far beyond the certified and certifying organizations. Industry and other groups, including consumers and environmentalists, must see these standards as legitimate if they are to be used. Although they have profound implications for public-policy choices on both a national and international level, this group of harmonized global standards, with the important exception of EMAS, are not only voluntary but are being developed privately. The private nature of the standard-setting process raises several interesting issues for international environmental law and policy, especially as compared to the better-known public international lawmaking process.

First, instead of the usual multilateral or regional fora where states are the only decision-makers - admittedly counseled, assisted and lobbied by private groups - here the state is merely one actor among many (or, in the case of business codes of conduct, is completely absent). While state-run standardization organizations participate in ISO, they are not the dominant force; each national or liaison delegation gets a vote, and within each delegation government officials have no special pride of place. ${ }^{129}$

The ISO standards' formation process supports a view of international law as composed not just of formal interactions among sovereign states, but as involving individuals, corporations, non-governmental organizations (NGOs), intergovernmental organizations like those related to the United Nations, and sub-national governments, as well as states. ${ }^{130}$ In this view, the state is the major agent in rulemaking and creating international norms, but it is not the only player. Rather, it is the intersection of the public and private, domestic and international spheres that creates the rules.

\footnotetext{
${ }^{129}$ Liaison organizations are generally intergovernmental or non-governmental organizations. They may be allowed to vote in work groups.

${ }_{130}$ Richard Falk, among others, has long been a proponent of this multilayered view of international society. See, e.g., Richard FALK, Revitalizing InTERNATIONAL Law (1989), especially Chs. 1 and 2. It is also reflected in liberal theories of international relations. See generally AnnMarie Slaughter Burley, International Law and International Relations Theory: A Dual Agenda, 87 Aм. J. INT'L L. 205, 232 (1993). Burley and other scholars have identified three theoretical approaches to international relations: realism, institutionalism (or, more specifically, regime theory) and liberal theory. Both realism and institutionalism assume states to be the sole and essentially unitary actors on the international scene and do not attempt to unlock the "black box" of state sovereignty. They differ in their views as to the nature of conflict and cooperation among states. Liberal theorists, in contrast, begin with the interests of individuals and groups in both national and transnational society, which influence the preferences and interactions of states. See Benedict Kingsbury, The Tuna-Dolphin Controversy, the World Trade Organization, and the Liberal Project to Reconceptualize International Law, 5 YвІEL 1, 7 (1994).
} 
The once sharp distinction between the national level, with its developed legislative, enforcement, and compliance mechanisms, and the international level, where no such mechanisms exist, has blurred. Rather than national or international, the process, and the result, have become transnational. ${ }^{131}$ Here, publicly generated national rules combine with a liberalized system of internationally generated trade rules to create conditions for privately generated international rules, which result from debate on both the national and international level. These will then be applied as both national and international standards and enforced through both national and international private mechanisms as well as public interventions.

The environmental arena particularly exhibits this blurring of lines between the domestic and the international, in part because of the global ramifications of many important environmental problems, ${ }^{132}$ and in part because the prevention and control techniques used in international environmental instruments borrow heavily from those used in domestic laws. At both the domestic and international levels, solutions require more than action at the level of the state: they require private parties to change their behavior by modifying production or disposal practices, installing pollution control devices, engaging in planning exercises, changing land-use patterns, and the like. Generally, international environmental law harnesses the coercive and persuasive power of the state to obtain these behavioral changes. This multi-step, multi-level character makes international environmental regulation a particularly transnational activity.

States, of course, are far from superfluous in the private process. The ISO negotiators simultaneously reflect the culture and regulatory climate of their respective states and supersede it. Much of the debate over ISO 14001 between a US-led camp and a European camp arose out of the differing conditions of regulation, liability, and public opinion in those places. A public law negotiation would have reflected similar differences. The private process, however, is not a simple transposition of "state" positions to the private sphere, because the predominance of non-state actors changes the dynamics.

131 The term "transnational" was first associated with the work of Philip Jessup, who stressed that it includes the relations of an economic, commercial, cultural, and social character across national borders, not merely interstate relations. The McDougal/Lasswell line of scholarship in international law also stresses the complex nature of decision-making processes in transnational society. See, e.g., Myres McDougal, International Law, Power and Policy, 82 Hague ReCueIl 137 (1953). As one scholar put it, the international becomes "not [] a departure, but [] a continuation of the terrain upon which law participates in ongoing social, cultural and economic conflicts and negotiations." David Kennedy, The International Style in Postwar Law and Policy, 1994 Utah L. Rev. 7, 28.

132 Some problems, such as climate change, ozone depletion, and loss of biodiversity, are clearly global in dimension. Others, like acid rain, are regional in scope. But even those problems traditionally considered "local," like air and water pollution and waste disposal, often have unanticipated global effects. For example, toxins dumped in local waterways often eventually end up in pristine ecosystems thousands of miles away. The difference between local and global effects is one of emphasis and degree, not kind. 


\section{I4O YEARBOOK OF INTERNATIONAL ENVIRONMENTAL LAW}

For example, the reduced degree of public visibility and accountability of the private process may cause political and economic positions taken in negotiations to be less aimed at a domestic political audience and to be less subject to change depending on the political complexion of the regime in power. ${ }^{133}$

Nonetheless, the non-state dominated nature of the standard-setting process does not necessarily guarantee adequate representation of societal interests. Rather, it can skew negotiations even further in favor of a given group-in this case, large transnational industrial producers. The ISO process also reflects the increasing ability of transnational business to intervene directly in public arenas when its interests are at stake. ${ }^{134}$ The dominance of global business concerns in the drafting process raises questions about the legitimacy of the process and the results.

\section{B. Limits to the Drafting Process of ISO 14000}

The ISO attempts to create legitimacy through formal requirements for broad-based participation. The ISO's constituent national groups are to bring together the interests of producers, users (including consumers), governments, and the scientific community. ${ }^{135} \mathrm{~A}$ balance of interests among these groups is presumably ensured because each national standards organization is required by its own rules to seek such balance. ${ }^{136}$ Other ISO internal rules attempt to ensure procedural fairness: comments must be addressed, all negative votes must be considered, ${ }^{137}$ and a supervisory body must assure that proper procedures have been followed. ${ }^{138}$

133 Note, for example, the divergences in the position of the UK, which in many state-centered negotiations (i.e. in the European Union) has opposed any expansion of international duties of environmental protection. See, e.g., David Willison, Italy: Green Rights for Citizens and Strong Community Powers Over Environment Protection-Rome Summit, Dec. 14, 1990, Reuter Textline Guardian; and the UK delegation's position in the ISO 14000 negotiations, where it opposed watering down the draft EMS standard. The existence and successful implementation of BS 7750, a stronger British national EMS standard, probably explains part of the difference, as does Europe-wide concern for a standard that can be used with EMAS. But so does the delegation's independence from the policies of the Major government. Similarly, the US delegation's positions probably would have varied had this been a government-only negotiation.

134 Some 300 corporations control a quarter of the world's productive assets. Many have gross revenues larger than the gross national products of states. See Richard J. BARNET \& John Cavanaugh, Global Dreams 14, 423 (1994). On the weakening of state authority by the spread of an "international business civilization," see Susan Strange, The Name of the Game, in Sea-Changes: American Foreign Policy in a World Transformed 238 (Nicholas X. Rizopoulos ed., 1990).

135 International Organization for Standardization, Information About ISO (Jan. 1993) (on file with author)

137 Negative votes may, however, be rejected as "not related" or "not persuasive." See Robert J. Hamilton, The Role of Nongovernmental Standards in the Development of Mandatory Federal Standards Affecting Safety or Health, 56 Tex. L. Rev. 1329, 1357-58 (1978) (describing process of ASTM, a constituent member of ANSI responsible for most US standard-setting). According to Hamilton, some consumer representatives felt their objections were often rejected on these grounds. $I d$.

138 American National Standards Institute, Procedures for the Development and Coordination of American National Standards 3.3 (1995). 
But in actuality, all major stakeholders have not been fully represented. This was especially so at the early stages, when the basic "architecture" of the standards was put in place. Despite the stated goal of balance, the membership of TC 207 is heavily concentrated in large global industry, industry trade associations and consultants, and industry-related government standard-setting bodies. The chairpersons of the technical committee subcommittees include representatives of the Merck and Bayer pharmaceutical giants, environmental consulting firms, and national standard-setting institutes. ${ }^{139}$ At the work-group level, where most of the drafting work is done, 10 of the 16 original conveners came from large corporations or industry federations. ${ }^{140}$ As late as the May 1994 plenary meeting of the technical committee, few consumer organizations attended, and only as "external liaisons," rather than participants. ${ }^{141}$

In practice, those who consistently attend meetings and participate in the actual drafting work decide the content of the ISO standard. The drafting committees are considerably less representative than the formal technical committee membership, and have been dominated, especially within the United States, by large corporate interests. Small businesses and consumer and environmental groups have been under-represented. ${ }^{142}$ This is so in part because the costs of participation add up: recent international meetings were held in Australia, France, Korea, Norway, and South Africa. While the intent is to distribute the costs of travel evenly, the result is that only those who can afford to pay thousands of dollars in travel costs may consistently attend meetings. ${ }^{143}$ Those tend to be representatives of the global

139 GEMI, Organizational Structure of ISO/TC207: Environmental Management and U.S. PARTICIPATION Chart (1994). In drawing conclusions from this list, one must keep in mind that although participants were delegated from their corporation to participate in the process, they often come from the corporation's environmental compliance shop rather than top management, and it is unclear to what extent they represent the views, and commitment, of the corporation's leadership.

$140 I d$.

141 At some point in the process, nonparticipation by NGOs may be the result of an assessment that the standards will have little substantive impact and thus are not worth spending scarce resources to influence. But that result in turn may reflect an earlier lack of NGO input into the decisions on the procedural or substantive content of the standards.

142 These problems seem endemic to voluntary consensus standard-setting. In a 1978 article on elaboration of US safety or health standards, Professor Robert Hamilton found that the US standard-setting committees suffered from a lack of qualified representatives for some important interests, uneven attendance, and a lack of balance on important working groups. Hamilton, supra note 137, at 1355. Hamilton expressed concern that standards may have been developed with insufficient participation by consumers, workers and small business, and that certain non-economic interests may have been given inadequate consideration in developing a consensus when most of the participants were representatives of economic interests. $I d$. at 1386 . Similar concerns apply in an international context.

143 Formal requirements for participation in national groups seem minimal. In the United States, for example, members of the technical advisory group are largely self-selected: upon payment of $\$ 250$, anyone can request membership. ASTM, US ADMINISTRATOR OF THE TECHNICAL ADVISORY GROUP, FACT SHEET (on file with author). Prospective members' names are 


\section{I42 YEARBOOK OF INTERNATIONAL ENVIRONMENTAL LAW}

corporations who have the most to lose or gain by how a standard is drafted. The dominance of transnational corporations is magnified by the existence of corporate subsidiaries in a number of participating countries. Thus, the same corporate or industry interests have multiple entry points into the drafting and decision-making process. ${ }^{144}$

The presence of government, small business, and NGO interests on TC 207 did improve over time, as word of the possible implications of ISO's work began to spread. The Netherlands provided a one-time, two-year grant to pay travel costs of under-represented interests and countries, ${ }^{145}$ although for the long term the travel issue remains unresolved. Government agencies like US EPA, which had preferred until 1994 to watch the process from afar, began taking a more active role. Large, relatively well-funded NGOs like the Environmental Defense Fund and Worldwide Fund for Nature also began attending meetings regularly. Nonetheless, NGO input has been largely damage control, rather than helping shape the form and content of the standards. ${ }^{146}$ By the time these new actors became engaged in the process, most of the basic decisions (at least on the ISO 14001 and other EMS documents) had already been made.

Although it may have happened too late, the private process, once composed almost exclusively of those with a pecuniary stake in the outcome of the exercise, eventually began to look more like the public one, with its messy and time-consuming, but ultimately legitimacy-enhancing, proliferation of interest groups. In addition, the proportion of professional lawyers and public standard-setters as opposed to technical and engineering personnel also increased over time. These actors were not simply lobbyists but actually sat at the table. This could be seen as an improvement over the public process, where NGOs find themselves pacing the halls or relegated

periodically distributed to existing members of the technical advisory group. Existing members must specifically vote to exclude applicants, and this rarely happens. Telephone Interview with Gordon Bellen, US technical advisory group member (May 1994).

144 The technical committee leadership is aware of the lack of balance and the price paid in lessened credibility of the final standards, although they see the pro-industry slant of some delegations internationally as balanced by the government- or consultant-heavy bias of others. Cascio, supra note 79 , at 48 . In addition, any tendencies of corporate-dominated drafting groups toward lax standards is to some degree mitigated by the professional norms of the environment, health and safety specialists like Joe Cascio who often represent the corporation. As another example, Joel Charm, head of one of the working groups, is the director of occupational health, in the corporate health, safety and environmental sciences office of Allied Signal.

145 Mary McKiel, US EPA, Report on Annual Meeting of the ISO Technical CoMmitTeE fOR ENvironmental MANAGEMENT 2-3 (1995) (on file with author).

146 For example, NGO representatives reintroduced the idea of the environmental objective of labelling programs, which the United States had earlier managed to delete from the ecolabelling draft. Meeting minutes, Nov. 30, 1995. NGOs were also extremely active in the fight to scuttle a Canadian/Australian initiative to create specific management standards on forestry. See infra note 214 and accompanying text. 
to meeting sites far from the centers of decision. ${ }^{147}$ Moreover, standards are more likely to be actually implemented when those industries expected to use them are at the drafting table and can take the product back and "sell" it to their respective organizations.

In addition to the predominance of transnational corporate interests, another potential problem is the predominance of delegations from large industrial countries. Just as in public international negotiations, formal equality of national delegations masks functional inequality. The lack of timely developing-country input poses the danger that developing countries are less likely to find the standards legitimate and to implement them. It also creates the risk that such standards, even if implemented, may be ineffective in many developing countries.

In theory, a wide range of countries participate in crafting the standards: 42 participating-country and 14 observing-country delegations have expressed interest in the work of the technical committee. ${ }^{148}$ But far fewer countries have attended in practice, and fewer still participated actively in the drafting and debate process. For example, at a May 1994 plenary session held in Australia to facilitate the attendance of industrializing Asian countries, only five of 26 delegations came from non-OECD states, ${ }^{149}$ while 15 European states attended. ${ }^{150}$ Attendance by less-developed country delegations at meetings held in the United States and Europe has been even more sparse, although by July 1995 a sizeable number of developing-country delegations were able to attend the plenary. ${ }^{151}$ The most substantive disputes in the technical committee have involved the United States, Europe and, to a lesser degree, Australia, Canada, Japan, Korea, New Zealand, and South Africa. ${ }^{152}$ Moreover, while most developed countries can send only

147 For example, the NGO forum for the 1992 Rio Conference on Environment and Development, and the NGO forum for the 1995 Beijing 4th World Conference on Women were both located far from the site of government deliberations, and many NGOs had problems obtaining access. See Chinese Government Angers Delegates as Women's Forum Opens, Deutsch Presse-Agentur, Aug. 30, 1995.

148 Benchmark Environmental Consulting, supra note 56, at Annex 2. Quality Systems UPDATE, supra note 77, at SR-10, gives the number as 43, up from 22 in 1993.

149 Minutes of Australia meeting, May 1994 (on file with author).

150 Id.

151 An unofficial listing of TC 207 members present includes Brazil, Chile, China, Colombia, India, Indonesia, Jamaica, Korea, Malaysia, Mauritius, Mexico, South Africa, Thailand, Trinidad-Tobago, Vietnam, and Zimbabwe. Thirteen European states, Australia, Canada, Israel, Japan, New Zealand, Russia, Turkey, and the United States also fielded delegations. MCKIEL, supra note 145, trip report at 7.

152 For example, a consensus draft on Type I eco-labelling schemes was hammered out in May 1994 by delegations from Australia, Canada, France, Germany, Japan, Korea, the United Kingdom, and the United States. June 10, 1994 correspondence re SC3/WG1 (on file with author); the initial draft of an annex to the EMS standard, intended to overcome USEuropean differences, was drafted by a small group consisting of Austria, Canada, Germany, Japan, New Zealand, the United Kingdom, the United States and the International Chamber of Commerce. July 20, 1994 correspondence (on file with author). 


\section{I44 YEARBOOK OF INTERNATIONAL ENVIRONMENTAL LAW}

one or two delegates, about 70 people formed part of the US delegation to the July 1995 plenary session. ${ }^{153}$

Obstacles to less-developed country participation may include the cost of attending meetings, as well as difficulties in obtaining critical documents in a timely manner. ${ }^{154}$ Some participants may also have a sense that developing countries' involvement would be wasted effort because they ultimately will have no choice but to fall in line with whatever standard is finally approved. Nonetheless, as word of the potential implications of the ISO standards has spread, more and more less-developed countries have expressed interest. While participants in the ISO process seem aware of the dangers posed by a lack of developing-country participation, concern only belatedly translated into action, with developed countries granting limited and temporary travel funds for delegates from less-developed countries to attend plenary sessions. ${ }^{155}$ Remedying the problem, at least in time for possible revisions to the standards in five years, will require a more permanent financing arrangement, better information flow, more attention to early outreach among those sectors under-represented in the initial drafting process, and the political will of the dominant corporate, developed-country actors to enact these changes. ${ }^{156}$

Another "process" difference between public international law-making and the private ISO process is the lack of linkage of issues in the latter. Most recent environmental negotiations (of both treaties and soft law) have featured extensive and highly contested attempts to link or avoid linking environment and development issues. Thus, for example, developingcountry compliance with environmental rules is linked to adequate transfers of resources and technology. ${ }^{157}$ Such linkage has advantages and disadvan-

153 Of course, in public environmental treaty negotiations many of the same problems and discrepancies arise, but over time mechanisms, including travel subsidies and the use of NGO advisors for small states, have arisen to ameliorate the problems. To date those mechanisms are absent in the ISO context.

154 A number of delegates from developing countries claimed they did not receive critical documents from the technical committee Secretariat before the July 1995 plenary meetings. Small and Medium-Size Businesses, Along With Developing Nations, Face Challenges, QuALITY SYSTEMS UPDATE, July 1995, at SR-10.

155 Support for an ISO mandate to provide travel funds for under-represented states might come from the GATT's Agreement on Technical Barriers to Trade, discussed infra notes 191-199, which provides that

Members shall take such reasonable measures as may be available to them to ensure that international standardizing bodies and international systems for conformity assessment are organized and operated in a way which facilitates active and representative participation of relevant bodies in all Members, taking into account the special problems of developing country Members.

TBT Agreement, supra note 128, at 12.5 .

156 Nonetheless, for reasons described below, industry and industry associations in many developing countries have expressed interest in implementing the ISO standards.

157 See, e.g., United Nations Framework Convention on Climate Change, 31 I.L.M. 949 (1992) (entered into force Mar. 21, 1994); 1992 United Nations Convention on Biological Diversity, 31 I.L.M. 818 (1992) (entered into force Nov. 1993). 
tages. It runs the risk of endless deadlock and overexpansion of the subject under negotiation, but also allows for wider bargaining. ${ }^{158}$ The ISO process seems much more limited, both in the divisions and subdivisions of participants into subcommittees and working groups with finite mandates, and in the technical mantle placed over what is in essence a political as well as technical process. The narrow scope no doubt allows for faster negotiation, but at the cost of potentially ignoring relevant linkages.

\section{Substantive Limits of the ISO 14000 Standards}

The process limitations of the current ISO effort shade over into substantive shortcomings. Perhaps the greatest concerns revolve around watering down the standards to a lowest common denominator. The lowest common denominator problem results from the consensus nature of the process and the need for widespread conformity with the final product if the standards are to be voluntarily implemented. ${ }^{159}$ Although the ISO rules do not require absolute consensus, and indeed proposals have advanced to draft international standard status over the objections of some participants, ${ }^{160}$ an effort is made to accommodate the views of at least the major players. The danger is that disputed points will be omitted or papered over, leaving a standard with few specifics and fewer teeth. To the extent the standards replace or complement other forms of regulation, their relative lack of stringency implicates public policy concerns. It is especially worrisome if the standards are being set by those who have the greatest financial stake in their leniency.

As discussed in detail above, the drafting of the ISO 14000 series standards has been plagued with exactly such compromises. The result is a draft EMS standard that is a step backwards compared to the British standard that served as its initial template, compared to the European EMAS, and even compared to the existing codes of conduct of organizations like the BCSD or the CMA. In the area of performance indicators as well, the initial idea of sectoral measures was jettisoned in favor of more general indicators. Debates were generally resolved by adopting the least substantive, least demanding position or the one providing the greatest degree of flexibility to an organization's management. ${ }^{161}$

Studies of private standard-setting in the United States have found similar patterns. Publicly derived regulatory standards overall tend to be stricter than private ones. ${ }^{162}$ "Public agencies are more willing than private ones to

158 See Lawrence Susskind, Environmental Diplomacy 82-98 (1994).

159 See Peter H. Sand, Lessons Learned in Global Environmental Governance (1990).

160 For example, the EMS Specification standard was approved by a vote of $28-2$, the guidance standard by a vote of 26-3. Minutes, July 1995 meeting, TC 207, SC 1 (on file with author).

161 See supra notes 52-89.

162 Ross E. Cheit, Setting Safety Standards: Regulation in the Public and Private SECTORS 18 (1990). 


\section{I46 YEARBOOK OF INTERNATIONAL ENVIRONMENTAL LAW}

select early compliance deadlines, require use of unproven technologies, and regulate in a manner that interferes with traditional notions of managerial discretion." ${ }^{63}$ Precisely these characteristics of much public regulation were partially behind industry attempts to create alternatives. It is therefore not surprising that private standards would tend to lean in the opposite direction.

Of course, the public international law-making process suffers from many similar dynamics. Global standards must command widespread support because neither treaty ratification nor compliance with rules can be coerced. In addition, a principal source of debate in the ISO was the need for standards to be applicable to organizations of widely varying technological and economic capability. This is a common debate in the public arena, as developing countries argue that global standards must reflect their particular circumstances as well as those of richer states. The solution found in ISO was to water down a set of uniform standards, sacrificing content to achievability.

But that was not the only possible solution. Over time, the process of making public international environmental has developed a number of techniques for avoiding reduction to the lowest common denominator while allowing for the differing needs and abilities of states. These include extended timetables for compliance, provision of technical and financial assistance, and recognition of differentiated but equivalent obligations. ${ }^{164}$ To some degree, this was at least considered: a European "bridge" document, which would be applicable only to those organizations seeking certification under both EMAS and ISO 14001, may tighten the minimum obligations for European producers. No comparable tailoring annexes or addendums will be developed for industry in other developed countries, however, nor are there special provisions for small companies or lessdeveloped countries. The drafters of ISO 14000 seem to have rejected as unnecessary any special rules or guidance for small and medium-sized enterprises (SMEs) or developing-country industry, at least for now. ${ }^{165}$ In contrast, the European Commission has focused special programs, financing, and training on SMEs to foster their adoption of EMAS. ${ }^{166}$

163 Id. Public agencies are more likely to consider product bans, and to require immediate results. Id. at 153-54, 157-58. In part, the differences are due to the predominance of engineers in private standard-setting, compared to that of lawyers in public rulemaking. $I d$. at 18 .

164 See, e.g., Montreal Protocol on Substances that Deplete the Ozone Layer, 26 I.L.M. 1541, 1555 (1987), Art. 5; UN Convention on Climate Change, supra note 157, Art. 4. See generally Daniel Barstow Magraw, Legal Treatment of Developing Countries: Differential, Contextual and Absolute Norms, 1 U. Colo. J. InT'L EnvTl. L. \& Pol'y 169 (1990); SAND, supra note 159.

165 Small and Medium-Sized Businesses, Along with Developing Nations, Face Challenges, Quality Systems UpDATE, July 1995 at SR-9. The drafting committee, with few if any representatives of SMEs among its members, concluded that the needs of small to medium businesses had been addressed.

166 Interview with Manfredi Bellati, supra note 27; COMMISSION OF THE EUROPEAN Communities, List of Pilot Projects Financed, DG XI.C.5, EEC Reg. 1836/93, (Jan. 17, 1995) (on file with author). 
The lack of input from small business, developing countries, or NGOs at crucial points in the ISO decision-making process explains some of the difference in outcome, as does the fact that the drafters were largely engineers and technical specialists rather than diplomats. In addition, the initial goal of a single harmonized set of rules that would eliminate multiple registrations and facilitate trade also militated against consideration of differential treatment, since any multi-tiered scheme would complicate application of the standard. These trade-related considerations reduced the usefulness of the draft ISO EMS standard from an environmental standpoint.

A further consideration in comparing public and private rule-making processes is how the two interrelate. One possibility is that the private standards will be used to stave off further public regulation. Industry's history of attempted self regulation in the environmental and health and safety fields is a venerable one. For some of the drafters, the ISO standards are conceived in this vein as an alternative to government regulation, aimed at forestalling requirements that industry perceives as more onerous. ${ }^{167}$ For some environmental groups, the standards are an attempt to undermine and eventually supplant the more demanding requirements of EMAS. ${ }^{168}$

Certainly, one possible outcome is that industry will use ISO 14000 certification or registration to tout its "greenness" while staving off any more demanding voluntary or mandatory changes. In the long run, however, efforts to avoid public regulation through self policing have rarely been successful where the content or execution of the private standards was found inadequate. Rather, the development of a system of private standards showed that industry recognized the existence of a problem and was committed to solving it. It will be hard to pull back from that position. Indeed, if widespread adoption of the ISO 14000 standards results in little change in actual performance, that will be a strong argument that more potent measures are required. The current standards will then serve as a jumping-off point for what does and doesn't work. ${ }^{169}$

167 According to their backers, the standards "may, in some countries, obviate the need for certain regulatory 'command and control' initiatives." While "some companies will implement the standards to project the sincerity and credibility of their commitment to environmental protection, others will use them to help manage and maintain their regulatory compliance posture." Joe Cascio, International Environmental Management Standards: ISO 9000's Less Tractable Siblings, ASTM Standardization News, Apr. 1994, at 44, 47. Thus, standards development has two objectives: 1) proactive-aimed at streamlining regulations, fostering commerce, and improving performance; and 2) defensive - aimed at facilitating legal compliance while avoiding more onerous mandatory environmental requirements.

168 Green Auditing: EEB Mounts Campaign Against ISO Standards, Eur. ENv'T, Nov. 14, 1995, available in LEXIS, Envrn Library.

169 Oil pollution from ships and pesticide regulation provide examples of this phenomena. For details, see Naomi Roht-Arriaza, Shifting the Point of Regulation: The International Organization for Standardization and Global Lawmaking on Trade and the Environment, 22 ECOLOGY L.Q. 479, 532-34 (1995). 


\section{I48 YEARBOOK OF INTERNATIONAL ENVIRONMENTAL LAW}

Eventually the limitations of purely procedural standards may become more apparent. Many of the initial duties specified in international environmental law in the public sphere were essentially procedural in nature: duties to exchange information, to notify, to consult, to conduct assessments, and the like. ${ }^{170}$ Indeed, one of the salient characteristics of recent international environmental law is the drafting of framework conventions that set out general, largely procedural devices for periodic meetings, continuing consultation, scientific assessment, and information sharing. ${ }^{171}$ Over time, more substantive and specified duties have been added to the panoply of international legal tools through these mechanisms. The problem here is not simply with the procedural nature of the obligations, but with the lack of a clear path to move from the minimal initial obligations to stronger substantive ones. Nonetheless, a move in this direction may ultimately become more feasible.

\section{COMPLIANCE WITH AND EFFECTIVENESS OF VOLUNTARY STANDARDS}

\section{A. Potential Uses and Pressures For Compliance}

"Voluntary" standards mean that private companies' implementation will be driven by their perceptions of market opportunities and threats, not by government regulation. As discussed earlier, however, the voluntary nature of the standards is somewhat misleading, as in many cases firms will have little choice but to comply or lose substantial market advantages. It is, of course, still not known whether the market pressures the drafters are hoping will urge registration and compliance with the standards will in fact come into play. While the success of the ISO 9000 quality control standards gives grounds for optimism, buyers have a more immediate commercial reason to seek quality control assurance. Environmental assurance may only take on similar characteristics if consumers, or governments, make it a high priority for more than a narrow subset of goods and services.

To date, most US corporations have taken a "wait and see" attitude toward ISO 14000, participating in seminars and training sessions and installing their own environmental management and auditing systems. Few

170 For a history and description, see Harald Hohmann, Precautionary Duties IN INTERNATIONAL ENVIRONMENTAL LAW (1994).

171 See, e.g., 1985 Vienna Convention for the Protection of the Ozone Layer, 26 I.L.M. 1529 (1987), a framework convention that was followed by the 1987 Montreal Protocol on Substances that Deplete the Ozone Layer, 26 I.L.M. 1550 (1987) and, three years later, by the London Amendments to the Protocol, 1990 Adjustments and Amendments to the Protocol Adopted at the Second Meeting of the Parties, London, 30 I.L.M. 539 (1991), each containing more specific and stringent provisions. See also Geneva Convention on Long-Range Transboundary Air Pollution, 1979 Nov. 13, 1979, 18 I.L.M. 1442 (1979), which was followed by the 1985 Helsinki Protocol on SO2 emissions, 27 I.L.M. 707 (1988), the 1988 Sofia Protocol on Nox emissions, 28 I.L.M. 212 (1989). 
have expressed interest in seeking formal certification. Developing-country industry has been largely enthusiastic, and many companies have pledged to seek ISO registration or certification. Given the lack of developingcountry input discussed above, and the undeniable costs of implementation, this enthusiasm bears explanation. One possibility is that developingcountry industry is especially interested in achieving the "green" image necessary to sell in major OECD markets, and sees ISO 14000 as a relatively painless way to do so. Another is that registration is a preemptive effort to head off proposed rules on "eco-dumping." 172

In Europe, the most immediate question is whether the draft ISO EMS standard as currently drafted will satisfy the requirements of Article 12 of EMAS. In 1995, the Commission asked the Committee for European Standardization (CEN) to develop or adopt existing standards that support Article 12, and CEN is widely expected to recognize ISO $14001 .{ }^{173}$ The differences, outlined above, would be resolved through a "Euro-annex", for application in the EC only. This annex, labelled an "informative guide" rather than a mandatory requirement (to avoid possible challenges as a trade barrier), would contain additional environmental and auditing requirements. CEN was to propose a standard to the EMAS Article 19 committee by mid-1996.

If ISO 14001 is accepted for use with EMAS, it will no doubt hasten the use of the standard among European companies, especially if it replaces existing national standards. Nonetheless, both EMAS and the ISO 14001 standards are designed to stand alone. A company may choose to seek registration to either one, or to implement them internally, for a number of reasons. One was alluded to above: increasing attention to pollution prevention as a cost-saver and cost-avoider. Even if the standards are only voluntary, they will force greater numbers of people within each company and each industrial plant to consider the environmental effects of their actions

172 As a result of increased attention to the debate over trade and the environment, academics, activists, and lawmakers in the United States and Europe have proposed that antidumping laws be expanded to include the concepts of "social dumping" or "eco-dumping." See, e.g., International Pollution Deterrence Act of 1991, S. 984, 102d Cong., 1st Sess. (1991), which, had it passed, would have authorized countervailing duties based on the additional costs a foreign firm would have to pay to comply with US environmental standards. A lack of adequate environmental regulation or effective enforcement would be characterized as dumping. Hence the imported goods would be subject to countervailing duties equal to the amount that the exporter was thought to have saved by not having to install appropriate controls. Alternatively, the lack of environmental regulation could be characterized as an indirect subsidy which, if it affects export shares would also be subject to retaliation.

These proposals, of course, beg the question of what constitutes "adequacy" or "appropriateness." Without an international standard, the tendency will be to define these terms relative to national regulations, inevitably raising suspicions of protectionism, or at least of discrimination against developing country exports. See Daniel Esty, GreEning the GATT 156-57, 163-66 (1994).

173 Quality Systems Update, July 1995, supra note 165, at SR-7; EC Plans to Bridge Gap Between ISO 14001 and EMAS, ENDS REPORT 247, Aug. 1995, at 38. 


\section{I5O YEARBOOK OF INTERNATIONAL ENVIRONMENTAL LAW}

and to take environmental factors into account when planning new products or processes. Because the standards have few substantive requirements, such consideration may not lead to changes in industrial design or financial planning. However, the timing of the standards dovetails with the rethinking of "industrial ecology" by engineers and planners. ${ }^{174} \mathrm{~A}$ small but growing number of producers are experimenting with and implementing changes in materials and industrial processes to reduce wastes and inputs of raw material. Often, companies can justify such changes because they reduce costs and increase productivity and efficiency, ${ }^{175}$ although as the easy changes are made, such cost reductions may diminish in importance. ${ }^{176}$

Internally-driven compliance with voluntary standards, however, may well depend on a continuing tightening of regulatory standards at the national level. The shift to pollution prevention has been partly driven by increases in waste-disposal fees due to limitations on dumping and controversies over hazardous waste dumps and incinerators, and by stringent rules on water and air quality. ${ }^{177}$ If a climate of deregulation and a rollback of environmental statutes takes hold in major world markets, the necessary incentives to seeking alternatives to regulation may dissipate.

Others may also make use of the standards. Companies might use certification or adherence to the standards as a benchmark for choosing suppliers or contractors, especially in publicity-sensitive industries or in those where ISO 9000 quality-control certification is already a prerequisite

174 Industrial ecology provides a systems perspective on the flow of materials and energy needed to create and produce industrial products. It looks at energy use, material choices, product and process design, material and waste management, market responses, and other factors to design sustainable systems of industrial production. Deanna J. Richards et al., The Greening of Industrial Ecosystems: Overview and Perspective, in THE GreENING OF INDUSTRIAL Ecosystems 1, 17 (Branden R. Allenby \& Deanna J. Richards eds., 1994).

175 See US Congress, Office of Technology Assessment, Serious Reduction of Hazardous Waste for Pollution Prevention and Industrial Efficiency, OTA-ITE-317 (1986); Joel S. Hirschiorn \& Kirsten V. Oldenburg, Prosperity Without Pollution (1991); 3M Corp., Pollution Prevention Pays: Status Report (1994) (3M claims to have prevented 177,000 tons of air pollutants, 18,200 tons of water pollutants, and nearly 2.7 billion gallons of wastewater from entering the environment, at a cost savings of $\$ 710$ million for the company).

176 See Frederick R. Anderson, From Voluntary to Regulatory Pollution Prevention, in THE GREENING OF INDUSTRIAL ECOSYSTEMS, supra note 174 , at 101 . In addition, the cost considerations involved may depend heavily on the regulatory climate, i.e., high waste disposal fees caused by bans on land dumping or injection, and so may not apply where this climate is lacking.

177 See, e.g., the US ban on land dumping in the Resource Conservation and Recovery Act, 42 U.S.C. $\$ \$ 6901-6992 k$ (West 1992 \& Supp. 1995); the strict limits on ocean dumping of wastes in the Marine Protection, Research, and Sanctuaries Act of 1972, 33 U.S.C. $\S \$ 1401-1445$ (West 1994); the European Directives on bathing water, Council Directive 76/160/EEC, Dec. 8, 1975, OJ 1976 L 31, p. 1, and on drinking water, Council Directive 76/440/EEC, June 6, 1975, OJ 1975 L 194, p. 26; and the Basel Convention on Hazardous Wastes, Mar. 22, 1989, 28 I.L.M. 649 (1989), which prohibits the transfer of hazardous waste from OECD to non-OECD countries 
to entry. ${ }^{178}$ Companies may find themselves with little choice about complying if a major competitor is advertising its compliance. Banks and insurance companies may require corporate clients to implement EMS and auditing systems to reduce their own potential exposure for environmental harms, at least in states where environmental liability is a major risk. ${ }^{179}$ They may also require specific environmental insurance in risk-prone industries. The premiums for such insurance may be pegged to environmental performance and may be unavailable in particularly damaging or risky industries. ${ }^{180}$

Institutional investors, especially those managing public funds or associated with "socially responsible investment," may look to certification or at least to implementation of EMS and auditing principles as part of their investment "screens." Tort litigants may well turn to compliance with environmental management systems as benchmarks for what was possible, or even customary, in establishing compliance or non-compliance with the standard of care. In the criminal area, compliance with the standards might influence both state and federal prosecutors enforcing environmental laws and judges applying the federal corporate sentencing guidelines. ${ }^{181}$ Governments may use them as a shorthand way of demonstrating compliance with permitting requirements, thus reducing regulatory inspections of the plants of certified organizations; indeed, some US states and other governments are considering this option. ${ }^{182}$ Others may incorporate them into

178 Quality Systems Update, July 1995, at SR-2; Peter N. Grabosky, Green Markets: Environmental Regulation by the Private Sector, 16 L. \& PoL'y 419, 429-30 (1994), provides the examples of British Telecom, which encourages prospective suppliers to explain their plans for improving environmental performance, and Volvo, which asks that suppliers comply with its own environmental policy.

179 See Grabosky, supra note 178, at 436. As Grabosky points out, banks and insurance companies may at times require environmentally damaging practices as well, as in the insistence that farmers use harmful fertilizers and pesticides on crops in order to obtain crop insurance.

180 See Marcia E. Williams, The Corporate Response to Government Institutional Controls and Information Gathering, in Transnational Environmental Law and ITS IMPACt on Corporate Behavior 84, 87 (Eric J. Urbani et al. eds., 1994).

${ }^{181}$ Bell \& Connoughton, supra note 70. Under 1991 Department of Justice guidelines, regulated entities that perform environmental audits, and those that have "regularized, intensive, and comprehensive" environmental compliance programs in effect will be treated more leniently in both prosecution and sentencing. US DePT. of Justice, Factors IN DeCisions on Criminal Prosecution for Environmental Violations in the Context of Significant Voluntary Compliance or Disclosure Efforts by the Violator 3-4 (1991). The US sentencing guidelines for federal crimes provide for more lenient penalties if an organization has taken "reasonable steps to achieve compliance with its standards, e.g., by utilizing monitoring and auditing systems reasonably designed to detect criminal conduct by its employees and other agents." United States Sentencing Commission, Guidelines Manual §8A1.2, comment (k)(5) (1993).

182 Quality Systems Update, July 1995 at SR-3. See also Ira Feldman, Escape from Command and Control?, ENvTL. Forum, Nov./Dec. 1995, at 39 (ISO 14000's greatest long-term driver could be regulatory applications). 
voluntary pollution prevention programs like US EPA's environmental leadership program. ${ }^{183}$

The standards will generate large amounts of information on environmental impacts of industrial activity. Existing information-based regulatory strategies like the US Toxics Release Inventory have proven effective in prodding companies to reduce toxic releases, ${ }^{184}$ yet the Inventory and other schemes cover only a small percentage of all chemicals used in industry. The existence of data will create pressure from consumers, neighbors, regulators, and non-governmental groups for its disclosure. That pressure may be exercised through negotiations with local groups, adverse publicity, threats to obstruct future permitting procedures, or as part of settlement negotiations with regulators over compliance with environmental laws.

ISO 14000 's failure to require any public access to information on environmental impacts substantially weakens the market effects of data compilation. ISO, as noted, contains no requirement for publication of information on an organization's environmental performance, requiring an organization to publish only its environmental policy. In contrast, EMAS does require such publication, in line with an emerging trend in international law to stress openness and access to information as fundamental to solving environmental problems. Agenda 21,185 the recent ECE rules on

${ }^{183}$ Mary McKiel of EPA suggested that ISO 14000 might be a tool within the EL program. Quality Systems UpDate, July 1995, at SR-8.

${ }^{184}$ The TRI is a reporting system established under the Emergency Planning and Community Right to Know Act, 42 U.S.C. $\$ \$ 11001-11050$ (West Supp. 1992), which requires US corporations to report yearly on emissions of 320 toxic chemicals above a de minimis amount. Many toxics, however, are excluded from the TRI. See Frances H. Irwin, An Integrated Framework for Preventing Pollution and Protecting the Environment, 22 ENVTL. L. 1, 47 (1992). Other US environmental laws, including Title III of the Superfund Amendments and Reauthorization Act (SARA) require companies to provide information regarding certain toxic materials they store and emit from their facilities. See also the Toxic Substances Control Act, 15 U.S.C. $\$ \$ 2601-2692$ (West Supp. 1992) and the 1990 Pollution Prevention Act, 42 U.S.C. $\$ \S 13101-13109$ (West Supp. 1992), for other informationgathering US laws.

185 Agenda 21 recommends that companies report annually on their environmental records, including use of energy and national resources and that industry adopt voluntary right-toknow programs based on international guidelines, including sharing of information on accidental and potential releases as well as reporting on annual routine emissions of toxic chemicals, "even in the absence of host country requirements." (Chs. 19.51(c), 30.10(a).) Industry should also provide data to governments, and, to the greatest extent possible, taking into account legitimate claims of confidentiality, to the public, on potentially hazardous substances (Ch. 19.16) and hazardous wastes (Ch. 20.23(a)). Governments should "encourage industries to be transparent in their operations and provide relevant information to the communities that might be affected by the generation, management and disposal of hazardous wastes." (Ch. 20.14(f). U.N. Conference on Environment and Development, Agenda 21: Adoption of Agreements on Environment and Development, U.N. Doc. A/CONF. 151/4 (Parts II and III), April 22, 1992. 
access to information, ${ }^{186}$ the EC Directive on the same subject, ${ }^{187}$ and numerous declarations and guidelines stress the importance of making available to the public as much information as is needed to critically judge the environmental effect of activities. ${ }^{188}$

Underlying the market-driven approach is the idea that others will prefer environmentally superior goods and services, or at least will avoid environmentally risky ones. That preference will be reflected in increased sales, lower liability, and increased public acceptance. But the lack of publicly accessible information about actual performance makes it more difficult for the market-driven approach to work. Markets can only respond to the proper signals if all players in the market have adequate information on which to base decisions. Under the ISO 14000 management system standard, the only signal is the self certification of the industry or firm itself, or the seal of approval of an outside verifier. But because no other information is available to confirm on what basis self certification or third-party verification has been granted, there is no way to verify the verifiers. Moreover, the lack of disclosure makes it impossible to check whether mere conformance with the EMS is accompanied by any real changes in performance.

The problem, in sum, is that third parties will be using a "seal" of environmental probity that represents less than meets the eye. As discussed above, compliance merely represents adherence to a set of management systems, not a preferred or even minimal level of performance. To the extent that the current ISO EMS replaces or defers other more substantive efforts, its application could be a setback for efforts at industrial environmental responsibility.

186 U.N. Economic Commission for Europe, Ministerial Conference Environment for Europe, Draft Guidelines on ACCESS to Environmental INFORMation and Public Participation in Environmental Decision-Making, ECE/CEP/24, Sofia, Bulgaria, Oct. 23-25, 1995. While aimed primarily at public authorities and bodies that have public responsibilities for the environment, the guidelines call on states to "encourage entities whose activities have a significant adverse impact on the environment to report regularly to the public on the environmental impact of their activities." Id. at I(14). Moreover, "public access to information stemming from such voluntary schemes as eco-audits should be encouraged, as should ecolabelling schemes for more environmentally friendly products." Id. at I(15).

187 Council Directive of 7 June 1990 on the freedom of access to information on the environment (90/313/EEC), 1990 OJ L 158 (June 23, 1990).

188 Admittedly, most of the treaties and declarations refer to the need for public access to information held by governments, not private parties. See, e.g., Convention on Climate Change, supra note 157, Art. 4 (inventory of emissions), Rio Declaration on Environment and Development, Rio de Janeiro, June 13, 1992, U.N. Doc. A/CONF.151/26 (vol. 1) (1992), 31 I.L.M. 874 (1992), Principle 10.2 (duty to allow residents of a state appropriate access to information). But some specify that industry must provide the relevant data to governments. See, e.g., OECD, Recommendation C(88) 85 of 8 July 1988: Provision of Information to the Public and Public Participation in Decision-Making Processes Related to the Prevention of, and Response to, Accidents Involving Hazardous Substances, 28 I.L.M. 277 (1989), Others leave implicit the need for the government involved to obtain the necessary data from industry. 


\section{I54 YEARBOOK OF INTERNATIONAL ENVIRONMENTAL LAW}

\section{B. Environmental Management Standards, Trade, and the Environment}

The ISO standards' importance also derives from recent changes in international trade law that make internationally recognized standards the preferred basis for national rules. Since 1974, international trade agreements have shown a preference for harmonized global standards. ${ }^{189}$ With the signing of the Final Act of the Uruguay Round (GATT 1994) ${ }^{190}$ the preference has become considerably stronger.

The Agreement on Technical Barriers to Trade (TBT), which is part of the GATT 1994, covers government regulations on products, like those relating to size, quality, or emissions levels. It states that "[w]here technical regulations are required and relevant international standards exist or their completion is imminent, Members shall use them, or the relevant parts of them, as a basis for their technical regulations." 191 It thus creates a preference for international standards, and a presumption that international rules are consistent with GATT. ${ }^{192}$

The TBT Agreement also now specifies that standards must be "no more trade restrictive than necessary" to meet a given objective. ${ }^{193}$ Unlike the

189 The 1974 Tokyo Round agreements included a supplementary agreement on Technical Barriers to Trade (the Standards Code) that generally required parties to use international standards where they existed. General Agreement on Tariffs and Trade, Multilateral Trade Negotiations, Agreement on Technical Barriers to Trade, MTN/NTM/W/192/Rev. 5, Mar. 29, 1979, Art. 2.2. See Steve Charnovitz, Environmental Harmonization and Trade Policy, in TradE AND the Environment: LAw, Economics, AND Policy 267 (Durwood Zaelke et al. eds., 1994). However, that agreement only applied to those states that specifically signed on. Less than half the parties to GATT 1948 were also parties to the Standards Code. See JoHN JACKsON, Restructuring the Gatt System (1990). Article 100 of the Treaty of Rome (which set up the European Economic Community) calls for the issuance of directives for the "approximation of such provisions laid down by law, regulation or administrative action in Member States as directly affect the establishment or functioning of the common market." Treaty Establishing the European Economic Community, signed Mar. 25, 1957, entered into force Jan. 1, 1958, 298 U.N.T.S. 11

190 Final Act Embodying the Results of the Uruguay Round of Multilateral Trade Negotiations, GATT Doc. MTN/FA (Apr. 15, 1994), reprinted in 33 I.L.M. 1125 (1994). The Final Act also established the WTO as a formal institutional structure for the GATT agreement. Id. at 1144. Here, the agreement itself will be referred to as GATT 1994 (as distinguished from the original GATT 1947), while the institution will be referred to as the WTO.

191 Agreement on Technical Barriers to Trade, supra note 128, Art. 2.2. The text continues: “. . . except when such international standards or relevant parts would be an ineffective or inappropriate means for the fulfillment of the legitimate objectives pursued, for instance because of fundamental climatic or geographical factors or fundamental technological problems." Id. Art. 2.4. Although this qualifier allows states to impose their own standards, it puts the burden on them to justify such departures.

192 For greater discussion, see Jennifer Schultz, The GATT/WTO Committee on Trade and the Environment: Toward-Environmental Reform, 89 AM. J. INT'L L. 423, 427 (1995). The TBT Agreement does not apply to government procurement, which is covered by the separate Agreement on Government Procurement. TBT Agreement, supra note 128, Art. 1.4.

193 Agreement on Technical Barriers to Trade, Final Act of the Uruguay Round p. 118, Art. 2.2. In addition, unlike the former Standards Code, the TBT Agreement now extends these rules to so-called "product-related PPMs," that is, process or production methods that have an effect on the final characteristics of the product itself. It does not, however, cover non- 
TBT's 1974 predecessor agreement, which was a separate, stand-alone agreement that only applied to those GATT contracting parties that specifically accepted it, the TBT applies to all parties to GATT $1994 .{ }^{194}$ Thus, if ISO's EMS and auditing standards become the international standard for trade purposes, they will obtain privileged status under international trade law.

Moreover, the new TBT Agreement encompasses non-governmental standardizing bodies. It commits central governments to take such reasonable measures as may be available to them to ensure that standardizing bodies comply with the national treatment and least trade-restrictive requirements of Article 2 of the Agreement, ${ }^{195}$ and with an annexed "Code of Good Practice for the Preparation, Adoption and Application of Standards." That Code contains similar non-discrimination language and generally requires standardizing bodies to use existing or imminent international standards as a basis for their own, and to avoid duplication of standards. ${ }^{196} \mathrm{An}$ equivalent set of non-discrimination rules applies to governments instituting conformity assessment procedures to make sure suppliers actually do conform to standards. ${ }^{197}$ In addition, states are to participate as fully as possible in creating international standards and international systems to assess products' conformity with standards, ${ }^{198}$ are to provide technical assistance to developing countries regarding their participation in international standardizing bodies, and are to encourage their national standardizing bodies to do likewise. ${ }^{199}$

product-related PPMs. See Janet Chakarian, PPMs and the GATT, in OECD, TRADE AND Environment: Processes and Production Methods 113, 115 (1994). It is thus unclear whether an EMS standard is covered by the TBT Agreement.

194 The sanitary and phytosanitary measures provisions of the agreement, which apply to food, crop, or livestock health, similarly generally require parties to base their rules on international standards, guidelines, or recommendations where they exist, and to insure that rules are not more trade-restrictive than necessary. Agreement on the Application of Sanitary and Phytosanitary Measures, Apr. 15, 1994, Arts. 3.1, 5.6, GATT, Final Act Embodying the Results of the Uruguay Round of Multilateral Trade Negotiations, reprinted in H.R. Doc. No. 316, 103d Cong., 2d Sess. 1382 (1994). These provisions caused great controversy because they would ostensibly require application of the pesticide residue and food safety standards of the Codex Alimentarius Commission. Those standards are considerably less stringent than those of the United States and many European countries. The use of international standards is not required if a party can show scientific justification or engages in a specified risk assessment protocol. Id. Arts. 3.3, 5. However, parties shall "avoid arbitrary or unjustifiable distinctions in the levels it considers to be appropriate in different situations, if such distinctions result in discrimination or a disguised restriction on international trade." Id. Art. 5(5). This may be problematic for states, like the United States, where different agencies administer inconsistent health-based standards. $\quad 195$ TBT Agreement, supra note 128, Art. 3.1. 196 Code of Good Conduct, Annex 3 to the TBT Agreement, supra note 128, at D, E, F, H. Standardizing bodies must use international standards as the basis for their own except "where [they] would be ineffective or inappropriate, for instance, because of an insufficient level of protection or fundamental climatic or geographical factors or fundamental technological problems." Id. at F.

197 TBT Agreement, supra note 128, Art. 5.

198 Id. Art. 9 and Annex 3. 


\section{I56 YEARBOOK OF INTERNATIONAL ENVIRONMENTAL LAW}

Three consequences arise from these trade rules. First, because international standards are to be given preference, more stringent national or regional standards may be open to challenge by exporting states meeting only the weaker ISO standard. ${ }^{200}$ Second, because GATT rules and sanctions are aimed at states, and not private actors, it is difficult to envision a GATT challenge to a private entity's application of the standards. Nonetheless, the new rules speak directly to the role of non-governmental bodies and put the onus on states to "take such reasonable measures as may be available to them"201 to ensure that private standard-setting bodies themselves treat domestic and imported producers alike; this may presage greater GATT attention to the state role in facilitating market-based mechanisms.

Third, if a government or the European Union incorporates the standards into public regulations that affect access to markets, ${ }^{202}$ the standards could be challenged. One possible avenue of challenge would be that ISO 14001 certification is easier and less costly for enterprises in parts of the world where verifiers/certifiers are plentiful than in those places where no accredited verifiers exist and companies must make long-distance arrangements to obtain certification. If the cost differential were significant, it might constitute a discriminatory effect on an enterprise in the latter situation. ${ }^{203}$ Another possible challenge might be impermissible differentiation among companies based on characteristics not inherent to the product as such-so called process and production methods (PPMs). Current GATT practice does not allow discrimination among imports based on the process or manner in which they were produced or harvested, although a definitive report has never been adopted. ${ }^{204}$ In the most famous clash to date between trade and the environment, the United States banned imports of Mexican tuna because the fishing method killed dolphins. A GATT dispute settlement panel concluded that the import restrictions on tuna caught with dolphindestructive methods were inconsistent with GATT because they "would not

200 As a practical matter, the issue would only arise if an exporter not certified to ISO 14001 could convince his or her government to raise the claim.

201 TBT Agreement, supra note 128, Art. 8.1.

202 Recall that EMAS may, at the time of its revision in five years, become to some degree mandatory.

203 GATT Art. III requires treatment of imports no less favorable than that accorded to like products of national origin in respect of all laws, regulations and requirement affecting their internal sale, offering for sale, purchase, transportation, distribution or use. There are exceptions for environmental purposes, but they are narrowly drawn. 1947 General Agreement on Tariffs and Trade, Geneva, Oct. 30, 1947, 55 U.N.T.S. 187, T.I.A.S. No. 1700, Art. III. See also sources cited note 205 , infra.

204 The GATT Council has never formally adopted the tuna-dolphin panel decisions, so neither has direct legal effect within the GATT/WTO system. See, e.g., Kingsbury, supra note 130 at 1 . Most commentators on the issue have criticized the non-recognition of PPMs as at least potentially valid environmental measures, arguing that moves toward sustainable development require attention to the ways things are produced. See e.g. articles cited in note 205, infra. 
directly regulate the sale of tuna and could not possibly affect tuna as a product." 205 To be consistent with GATT, trade restrictions must target imports based on their inherent product characteristics rather than on their environmental effects. ${ }^{206}$

It is not clear whether a strictly procedural EMS standard would qualify as a PPM, but a good argument could be made that implementation of an EMS system is a "process" standard even without any substantive limits on inputs or outputs. It is also unclear to what extent rules created by ISO and implemented through national standards organizations (which generally have some governmental members) could be challenged as creating de facto discriminatory effects so long as those rules were enforced through the market and not through regulation. But even if a formal challenge in the WTO is not forthcoming, the very existence of WTO preference for existing international standards in the environment area may discourage the development of other, possibly more demanding, national standards in the same subject area.

\section{From Procedural to Substantive Standards}

To date, the ISO draft standards lack specific commitments to emissions reductions, source reduction, materials or industrial process changes, or the like. The procedural changes they focus on may be a useful first step. But eventually, especially as initial cost-saving changes are exhausted, it is unlikely that management systems, auditing, and information alone can compel sustainable industrial development. ${ }^{207} \mathrm{~A}$ shift toward minimum substantive rules of environmental performance seems inevitable. Several alternatives have been proposed, including creating an international body

${ }^{205}$ GATT, United States-Restrictions on Imports of Tuna (Sept. 3, 1991), Panel Report No. DS21/R, reprinted in 30 I.L.M. 1594 (1995). The case concerned provisions of the US Marine Mammal Protection Act that prohibited imports of tuna from countries that failed to take sufficient measures to ensure the safety of the dolphins that swim with schools of tuna See Naomi Roht-Arriaza, Precaution, Participation and the Greening of International Trade Law, 7 J. Envtl. L. \& Litig. 43, 67-77 (1992); David J. Ross, Making GATT Dolphin-Safe: Trade and Environment, 2 DuKe J. Comp. \& INT'L L. 345 (1992); Robert Housman \& Durwood Zaelke, The Collision of the Environment and Trade: the Gatt Tuna/Dolphin Decision, 22 Envtl. L. Rep. (Envtl. L. Inst.) (April 1992).

${ }_{206}$ GATT, United States - Restrictions on Imports of Tuna, supra note 205, at para. 5.14. On May 20, 1994 a GATT dispute panel decided a second case on restrictions on tuna imports, this one challenging the secondary embargo provisions of the MMPA. That panel also adopted a view of GATT that prohibits restricting imports of products based on the manner in which they are made or harvested. GATT, United States- Restrictions on Imports of Tuna, Report of the Panel, reprinted in 33 I.L.M. 839 (1994). In addition, a panel recently held that processbased, rather than product-based taxes, and regulations were not valid internal rules under Article III of GATT. See GATT, U.S.-Taxes on Automobiles, DS31/R, Oct. 11, 1994 (EC challenge to US "gas guzzler" tax and corporate average fuel economy standards). For analysis of the "Auto Taxes" case, see Steve Charnovitz, The GATT Panel Decision on Automobile Taxes, 17 InT’L EnVtl. Rep. 921 (1994). See generally Kingsbury, supra note 130; articles cited supra note 205.

207 See Anderson, supra note 176. 
capable of setting substantive minimum environmental standards. ${ }^{208}$ Others propose a convention on minimum standards for manufacturing and processing industries that would use waste audits to establish baselines and then develop subsequent sectoral protocols. ${ }^{209}$ The ISO process contains the germ of several ideas that could form part of such a shift. This model would incorporate participation of actors other than states, private monitoring (or at least private financing) of compliance, minimum standards with differential treatment for small producers, technical assistance, and technology transfer. Most importantly, it would focus on producers and products, rather than states, as the point of regulation. ${ }^{210}$

Many of the proposals for substantive standards conclude that such standards or protocols should be established by sector to allow meaningful comparisons among firms, target the most heavily polluting sectors, and minimize competitive effects. Indeed, the idea of sectoral standards has been floated during the ISO negotiations several times. Early on, as described, several European-country delegations pushed for substantive performance indicators by sector, but this approach was abandoned. ${ }^{211}$

A second, more controversial sectoral proposal would have set specific environmental management standards for the forestry sector. The Canadian and Australian delegations jointly submitted the plan based on a Canadian Standards Association draft. According to the drafters, a specific interpretation of the EMS registration standard was necessary because of the longer planning period and other unique characteristics of the forestry industry, which created the danger of inconsistent and possibly arbitrary interpretations by ISO 14000 registrars. ${ }^{212}$

At a July 1995 informal debate on the proposal, two objections were raised. Many ISO delegates disagreed with the idea of specific sectoral standards, at least until the final generic EMS standard had been approved and tested. Sectoral standards would undermine the often-made argument that the ISO 14000 EMS standards may be used by all sizes and types of organizations. ${ }^{213}$ Second, environmentalists faulted the proposal as inadequate and misleading. They disagreed with an EMS-based approach to forest

208 See, e.g., Sir Geoffrey Palmer, New Ways to Make International Environmental Law, 86 Aм. J. INT'L L. 259 (1992) (tripartite institution modeled on ILO); Daniel Esty, GATTing the Greens, Foreign AfF., Nov./Dec. 1993, at 32 (the Global Environment Facility); Charnovitz, supra note 189 (institution modeled on ILO).

209 Gareth Porter, Environmental and Energy Study Institute, Multilateral Agreement on Minimum Standards for Manufacturing and Processing Industries (July 1994) (unpublished manuscript, on file with author).

210 The contours of this model are sketched out in greater detail in Roht-Arriaza, Shifting the Point of Regulation, supra note 169, at part VI.

211 See discussion supra note 70 and accompanying text.

212 Industry-Specific Requirements Questioned, Quality Systems Update, July 1995, at SR11.

${ }^{213} I d$. 
management, which included no mandatory measurable indicators of forest sustainability and merely certified the operability of a management system. They charged that it would lead to certification of companies that continued to engage in destructive practices on the ground, but that could then sell their products as having been "eco-certified." 214 In addition, a purely procedural standard would undermine existing more substantive efforts to create sustainable timber schemes. The proposal was withdrawn when it became clear that it would lose on a vote, but it may be reintroduced in 1996. ${ }^{215}$

Sector-wide voluntary standards that include more or less substantive obligations already exist in certain industries, generally those with high public visibility and a limited number of participants. ${ }^{216}$ In addition, the Netherlands has pioneered negotiated covenants between government and industry, which can either complement or take the place of mandatory legislation. Such covenants may commit either an industry association or individual industries, and are enforceable through civil law. They have been used to reduce the quantity of phosphates in surface water, to reduce air emissions, and to reduce discharges by the packaging, graphics, metallurgy, dairy, and chemical industries. ${ }^{217}$ Denmark and the Flemish region of Belgium have passed laws allowing for public enforcement and sanctions based on such negotiated agreements. ${ }^{218}$ The European Commission is discussing region-wide negotiated agreements on a company or sectoral level. ${ }^{219}$ In the United States, several companies have entered into substantive "good neighbor agreements" wherein they agree to local community participation in, and review of, environmental audits as well as substantive changes in operations. ${ }^{220}$

${ }^{214}$ For a detailed critique of the Canadian draft standard that was the basis of the proposal to ISO, see Michelle Swenarchuk, Canadian Environmental Law Association, An Environmentalist and First Nations Response to the Canadian Standards Association Proposed Certification System for Sustainable Forest Management (Nov. 1995) (unpublished manuscript, on file with author).

${ }^{215}$ Quality Systems Update, supra note 77.

216 See, e.g., supra text accompanying notes 17-22 (the chemical industry's Responsible Care initiative).

${ }^{217}$ Policy of Negotiating Environmental Pacts With Industry to Continue, Government Says, INT'L ENV'T ReP., March 23, 1994, at 274; Rob Gerits \& Jules Hinssen, Environmental Covenant for the Oil and Gas producing Industry: A Valuable Policy Instrument?, 24/6 ENVTL. PoL'y \& L. 323 (1994); Niels S.F. Koeman, Bilateral Agreements Between Government and Industry in Dutch Environmental Law, 2 Eur. ENvTL. L. Rev. 165 (1993).

218 Jesper Jorgensen, supra note 11.

219 Id.; see also European Commissioner for Environment Ritt Bjerregaard, speech at UNICE Seminar, Brussels, Belgium (Mar. 28, 1995) (on file with author)

${ }_{220}$ See Sanford Lewis, Precedents for Corporate Community Compacts and Good Neighbor Agreements (The Good Neighbor Project, Waverly, Mass.), 1995 (on file with author). Companies include Unocal Oil in California and Rhone Poulenc in Texas. Often, agreement comes as a response to local opposition to legal permits for continuing or expanded operations. $I d$. 


\section{I60 YEARBOOK OF INTERNATIONAL ENVIRONMENTAL LAW}

On an international level, the World Bank's recently revised Industrial Pollution Prevention and Abatement guidelines set out substantive emissions and design guidelines for Bank-funded industrial facilities projects, including a number that are sector-specific. ${ }^{221}$ For example, the guidelines specify emissions limits for fossil fuel thermal power plants and for pollutants from mining operations. OECD states recently agreed on a plan of action to eliminate the use of lead, including phasing out lead in gasoline and paint and encouraging industry to find substitutes for a range of leadbearing products. ${ }^{222}$ These precedents and proposals could serve as building blocks for a substantive set of international voluntary agreements. ISO or an organization like it might play a positive role with adequate changes to include small business, environmental and consumer groups, and lessdeveloped countries more fully in negotiations from the start. Although nongovernmental actors currently play an important role in treaty negotiations, that role is generally informal and excludes the ability to vote. ${ }^{223}$ Admittedly, increasing the number of actors at the negotiating table makes for more complex and extended negotiations. But the result would be more broadly representative, and hence legitimate, than entrusting the task to states alone or to an international civil service.

Under a more substantive standard, an environmental impacts register could be used to set baselines for environmental protection. The standards would set minimum or maximum levels for items such as energy and resource use, emissions, disposal and reuse obligations, use of certain damaging substances or processes, and protection of biological resources, local communities, and sensitive areas.

Organizations complying with the standards would seek certification; alternatively, goods produced within the guidelines would seek eco-labels. Compliance could be monitored and enforced through a combination of third-party certification and self certification for smaller producers combined with random third-party checks. Self certification would reduce the burden on small and medium enterprises. Such a certification scheme would help alleviate the current lack of public resources for enforcement of envi-

\footnotetext{
221 The guidelines, issued in August 1995, will replace a 1988 set of guidelines. Among the notable changes are a new emphasis on pollution prevention, industry-specific guidelines for thermal power projects, monitoring requirements, and the like. The guidelines apply to all projects in the pre-appraisal stage of World Bank or International Finance Corporation financing, and were developed together with the United Nations Environment Programme and the UN Industrial Development Organization. See Anne Goodwin, World Bank Environmental Guidelines Made Stricter, Focus More on Prevention," 18 InT'L Env'T ReP. (BNA) 604 (1995). The guidelines were issued to be used with the Bank's environmental assessment procedures, now set out at draft OP/BP 4.01.

${ }^{222}$ Marlise Simons, Rich Nations Urge Action to Cut Danger From Lead, N.Y. Times, Feb. 23,1996 , at A5, col. 1 .

${ }_{223}$ Susskind, supra note 158. See also Philippe Sands, The Environment, Community and International Law, 30 HARV. INT'L L.J. 393 (1989).
} 
ronmental obligations at both the national and international level. ${ }^{224}$ As austerity programs continue and budget constraints tighten in both developed and developing countries, the public sector will be less able to provide the resources necessary to enforce producers' environmental obligations, leaving the private sector as the only viable source of funding. A third-party certification system, like that used under the ISO 9000 process and contemplated under EMAS, would allow the costs of monitoring compliance to fall directly on the producers. ${ }^{225}$

This proposal would require rules for certifiers, strict checks, regular quality control over certifying bodies, and the development of a uniform certifying methodology. ${ }^{226}$ Even better, private certifiers could work in conjunction with environment ministry officials, thus combining technical assistance with a financing mechanism that does not further burden either poor countries or international organizations. ${ }^{227}$

A powerful, yet controversial extension of such a scheme would make certification a basis for preferential treatment in international trade. Domestically, certified goods could obtain preferential tax treatment. As a corollary, goods from certified producers would enter under special preferences or at lower tariff rates. Certification would allow goods that appear identical but are produced through different methods to be classified differently under tariff schemes. When tariff rates are already so low that preferential access would provide no benefit, the converse rule could obtain: goods from non-certified producers would face higher taxes and tariffs. This system would allow distinctions among producers based on production methods as well as products themselves. As such, it would admittedly violate current GATT jurisprudence on production and process methods, and so could not be implemented without a change in that jurisprudence. ${ }^{228}$ Moreover, developing-country governments might construe such attempts as yet another scheme to limit their exports. Technical

224 See, e.g., Joseph G. Block \& Andrew R. Herrup, The Environmental Aspects of NAFTA and Their Relevance to Possible Free Trade Agreements Between the United States and Caribbean Nations, 14 VA. ENvTL. L.J. 1, 13-15 (1994) (failure of environmental protection in Caribbean nations); Esty, supra note 172, at 156-57 (failure of developing countries to protect environment due to lack of resources, technical ability).

225 See supra text accompanying note 40 (use of third party certifiers in ISO 9000), and notes 26-17 (EMAS).

226 See Thurston, supra note 41, regarding negotiations for the development of a uniform certifying methodology under ISO 9000 . Similar efforts will be required under ISO 14000, as well as of any other system that relies on private certifiers. A draft standard for qualifications of environmental auditors was approved for voting in July 1995. See supra note 77 and accompanying text.

227 The United Nations' UNIDO Clean Production centers provide technical assistance to developing country industries in environmentally superior production techniques, but they are also understaffed and underfunded. UN Industrial Development Organization, National Cleaner Production Centres, Vienna, Austria (Oct. 1994).

228 See supra note 204 and accompanying text. 
and financial assistance for small and medium domestic industry might blunt that opposition.

Nonetheless, a producer or product-based scheme harnessing international trade would have a number of advantages. It would avoid penalizing environmentally responsible firms through multilateral or unilateral trade restrictions just because other firms located in the same place caused the state to violate its international responsibilities or to incur international sanctions. ${ }^{229}$ It would allow differentiation based on the real abilities of firms to comply with high standards of protection, not on the artificial criterion of whether the firm was located in a developing state. ${ }^{230}$ Thus, it would hold Mitsubishi or IBM to the same high standard whether their plants happened to be located in Thailand or Japan, while allowing for flexibility with respect to smaller producers. Consequently, global corporations would have less incentive to avoid responsibility for their environmental actions by shifting production from one state to another. ${ }^{231}$ There would also be less incentive for states to unilaterally decide to exclude or tax goods from certain countries based on a perception of the unfair competitive advantages created by "eco-dumping." Rather than the legislation of the importing country serving as the benchmark against which to measure the adequacy of national environmental legislation, an ISO-negotiated set of rules could provide a global standard.

\footnotetext{
229 For example, sanctions such as trade penalties, loss of development financing, or public opprobrium, inure to the state as a whole. Thus, when Mexican tuna fishing boats killed too many dolphins, the United States barred imports of all tuna from Mexico, even though some of the Mexican tuna boats probably carefully avoided killing dolphins. See US Marine Mammal Protection Act, 16 U.S.C. \$1371(a)(2) (1990) (prohibiting on tuna imports from countries without appropriate certification regarding dolphin mortality). Under this regime, the hope is that a state will regulate, fine, embarrass, or otherwise pressure its recalcitrant domestic producers into line. If it does not, there is little else states can do against the specific group of offending producers. International adjudication and sanctioning mechanisms remain largely unused in the environmental area.

${ }_{230}$ The use of the criterion of plant location rather than ownership of capital to determine how benefits for developing countries are determined has proven problematic in other areas. For example, studies of the Generalized System of Preferences system of preferential tariff treatment for developing countries have shown that many of the benefits actually accrue to the local subsidiaries of global corporations, with few multiplier effects in the local economy.

231 Admittedly, any criteria for differentiation - whether it be national versus global capital, or size of the plant/enterprise-will raise problems of definition at the margins and might lead to unwanted avoidance behavior on the part of firms. For example, if global or transnational corporations were expected to comply with stricter standards than national producers, joint ventures and shell corporations of all sorts might arise. If size were the relevant criterion, i.e., if some requirements had a "small and medium enterprise" exception, one might expect to find large conglomerates broken down into a large number of smaller, yet interlocking, enterprises. Any type of differential obligations will run into these boundary problems, yet they do not seem severe enough to invalidate the idea. On avoidance behavior by regulated entities, see generally Cass Sunstein, Paradoxes of the Regulatory State, 57 CHI.-Kent L.R. 407 (1990).
} 


\section{CONCLUSION}

Under certain conditions, private, voluntary standards may play a useful role. Such standards, if substantive, sector-specific, and created through a more inclusive process, may prove more easily monitored and enforced through market mechanisms than through an international regulatory agency. Such standards will never replace public rules-indeed, they can only exist within a context created by public law-but they could pave the way for future publicly generated rules. The current ISO process, while deeply flawed, contains the germs of a number of good ideas. And it reflects, for better or for worse, the increasing complexity and multi-dimensionality of international environmental lawmaking. 